\title{
LIETUVOS KARIUOMENĖS KAVALERIJA TARPUKARIU: REGULIARIEJI PULKAI, ŠAULIAI DRAGŪNAI IR TERITORINIŲ DRAGŪNŲ TARNYBA
}

\author{
Dr. Vytautas Jokubauskas \\ Klaipedos universiteto Baltijos regiono istorijos ir \\ archeologijos instituto mokslo darbuotojas
}

Pastaraisiais metais intensyveja ne tik apskritai Lietuvos karo istorijos, bet ir atskirų jos kariuomenès rūšių, dalinių ir igulų raidos tyrimai. Čia galima paminèti Gintauto Surgailio darbus, skirtus tarpukario Lietuvos kariuomenès pėstininkų pulkų istorijai ${ }^{1}$, Jono Vaičenonio ir Valdo Rakučio Lietuvos péstininkų nuo Lietuvos Didžiosios Kunigaikštystės laikotarpio iki XXI a. tyrimąa ${ }^{2}$ Klaipedos universiteto mokslininkų XX a. Klaipėdos karinès igulos studiją ${ }^{3}$. Bene išsamiausiai, nors ir aprašomuoju metodu, aptarta tarpukario Lietuvos kariuomenès karo technika ${ }^{4}$, karo laivynas, kurị sudarè tik vienas mokomasis karo laivas ir keletas pasienio policijos motorlaivių

\footnotetext{
1 Surgailis, G. Pirmasis pėstininkų Lietuvos didžiojo kunigaikščio Gedimino pulkas, 1920-1940 m. Karo archyvas, 2009, t. XXIV, p. 55-115; Surgailis, G. Pirmasis péstininku Didžiojo Lietuvos kunigaikščio Gedimino pulkas. Vilnius, 2011, 305 p.; Surgailis, G. Trečiasis pestininku Didžiojo Lietuvos kunigaikščio Vytauto pulkas. Vilnius, 2013, 192 p.; Surgailis, G. Antrasis Lietuvos didžiojo kunigaikščio Algirdo péstininku pulkas. Vilnius, 2014, 292 p.

2 Rakutis, V.; Vaičenonis, J. Lietuvos didžiojo kunigaikščio Algirdo mechanizuotojo péstininku bataliono istorija. Vilnius, 2012, 196 p.

3 Kareivines, tapusios Klaipédos universitetu: studija, skirta Klaipèdos universiteto Baltijos regiono istorijos ir archeologijos instituto 20-mečiui, Klaipédos universiteto 20-mečiui ir Klaipédos miesto 760-mečiui. Sud. V. Safronovas. Klaipèda, 2012, 260 p.

4 Grigoraitis, V. Lietuvos kariuomenès automobiliai 1919-1940 m. Lietuvos archyvai. Apie Lietuvos kariuomene, 1999, t. XII, p. 23-47; Grigoraitis, V. Lietuvos kariuomenès technika 1918-1940 m. Vilnius, 2009, $271 \mathrm{p}$.

5 Vareikis, V. M-59 - „Prezidentas Smetona“ - „Pirmūnas“ - T-51 „Otličnik“. Mažo-
} 
nuosekliai išanalizuota artilerijos ginkluotè ${ }^{6}$, priešlèktuvinè gynyba ${ }^{7}$ ir karo aviacija. Apskritai aviacija ir jos istorija domina plačius visuomenès sluoksnius, taigi nenuostabu, kad ir tarpukario Lietuvos karo aviacija sulaukè tyrèjų dèmesio. Daug prie karo aviacijos tyrimų prisidejo Algirdas Gamziukas, parengęs ne vieną originalų straipsnị ir knygą ${ }^{8}$. Kartu būtina paminèti Gytị Ramošką, kuris taip pat išspausdino ne vieną straipsnị ir knygąa: autorius itin daug nuveike tirdamas tarpukariu naudotus orlaivius. Didelis Algimanto Liekio veikalas Lietuvos karo aviacija (1919-1940) ${ }^{10}$, tačiau vertintinas kontroversiškai dẻl duomenų patikimumo. Šị leidinị J. Vaičenonis apibūdino kaip „abejotinos kokybės tekstą"11. Svarų indèlị ị Lietuvos karo aviacijos tyrimus įneše Lenkijos istorikas Waldemaras Rezmeris, pateikęs išsamią Lietuvos karo aviacijos analizę, kurios pirmas skyrius skirtas visos Lietuvos kariuomenès 1918-1940 m. apžvalgai ${ }^{12}$. Pastaraisiais metais pasirodè nauja Gintauto Deksnio knyga, kurioje nagrinejjama tarpukario Lietuvos karo aviacijos švenčių problematika, aptariama aviacijos atsiradimo ir raidos istorija, keliamas Lietuvos karo aviacijos tradicijų formavimo klausimas ${ }^{13}$.

ji Lietuva, 1991, lapkričio 14, Nr. 44 (134), p. 14; Surgailis, G. Lietuvos karinis laivynas 1935-1940 m. Vilnius, 2003, 207 p.; Adomavičius, R. Lietuvos sienų sargyboje: „Prezidentas Smetona“ 1927-1932 m. Po muziejaus burémis. Muziejininku darbai ir ǰvykiu kronika, 2010, Nr. 1, p. 18-37; Гайдук, А. А.; Лапшин, Р. В. Военно-морские сильь Прибалтийских государств 1918-1940 гг. Санкт-Петербург, 2009, 180 с.

6 Jokubauskas, V.; Papečkys, E. Lietuvos kariuomenès artilerijos pabūklai 1919-1940 m. Karo archyvas, 2012, t. XXVII, p. 163-231.

7 Lapėnaitè, J. Priešlèktuvinès apsaugos organizacijų kūrimas Lietuvoje. Istorija, 1998, t. XXXVIII, p. 39-45; Vaidotas, E. Priešlèktuvinès apsaugos rinktinè 1935-1940 m. Karo archyvas, 2010, t. XXV, p. 214-248.

8 Gamziukas, A. Aviacija Lietuvoje 1919-1940. Kaunas, 1993. 52 p.; Gamziukas, A. Kelio pradžia. Konstruktoriaus A. Gustaičio vaikystė ir jaunystè. Plieno sparnai, 1997, Nr. 4, p. $2-4$.

9 Ramoška, G. Lietuvos karo aviacija nepriklausomybès karuose. Plieno sparnai, 1994, Nr. 2, p. 2-9; Ramoška, G. Lietuvos aviacija. Kaunas, 2009, 167 p.

10 Liekis, A. Lietuvos karo aviacija (1919-1940). Vilnius, 1999, 759 p.

11 Vaičenonis, J. Lietuvos karo istorijos tyrimų organizavimas 1918-2008 metais. Istorija, 2009, t. LXXIII, p. 63.

12 Rezmer, W. Litewskie lotnictwo wojskowe 1919-1940. Toruń, 1999, 330 s.

13 Deksnys, G. Kilkime...: Lietuvos karo aviacijos švenčių apybraižos. Kaunas, 2009, 144 p. 
Taigi iš esmès dominuoja karo aviacijos, karo technikos ir laivyno tyrimai, nors tarpukariu Lietuvos kariuomenę sudarẻ 12 pagrindinių rūšių: pėstininkų, artilerijos, kavalerijos, aviacijos, inžinerijos, jūrininkų, intendantūros, ginklavimo, topografijos, teismo, sanitarijos ir veterinarijos specialybių daliniai ir tarnybos ${ }^{14}$. Todèl galima konstatuoti, kad mokslininku dėmesys sutelktas ị pėstininkų, artilerijos ir aviacijos analizę, nors išeivijoje 1986 m. išleistoje knygoje Vytenis Statkus apraše jas visas ${ }^{15}$, o kitos kariuomenès rūšys išsamesnių tyrimų vis dar laukia. Kavalerija - viena iš jų. Šiame kontekste, be V. Statkaus studijos, dar galima paminèti būsimo generolo ir Lietuvos kariuomenès vado Jono Vytauto Žuko 1991 m. publikaciją, kurioje jis aptare tarpukario Lietuvos kavalerijos kūrimosi aplinkybes, pulkų struktūrą ir ginkluotę, raidos tendencijas ${ }^{16} .1918-1921 \mathrm{~m}$. Lietuvos kavalerijos kūrimo sąlygas ir dalyvavimo karo veiksmuose ypatumus apžvelgia W. Rezmeris ${ }^{17}$. G. Surgailio teigimu, „be reguliariosios kariuomenès, dar buvo dviejų nepilnų eskadronų teritorinè dragūnų tarnyba" ${ }^{18}$. Vytautas Lesčius konstatavo menamas jos taktinio rengimo problemas ${ }^{19}$, aptarè 1938-1940 m. kavalerijos organizacijos, dislokacijos ir veiksmų 1939 m. rugsejjo mèn. įvairius aspektus ${ }^{20}$. Paminètinas ir Vytauto Didžiojo universitete Mindaugo Tamošiūno apgintas bakalauro darbas Lietuvos kariuomenés kavalerija 1919-1940 m.: tradicijos, kasdienybe, vizijos (paskelbtas ir internete $)^{21}$.

Analizuojant Lietuvos kariuomenès kavalerijos istoriją tarpukariu

\footnotetext{
14 Karinès tarnybos įstatymas. Vyriausybès žinios. Kaunas, 1936, Nr. 561, p. 2.

15 Statkus, V. Lietuvos ginkluotos pajégos 1918-1940 m. Chicago, 1986, 1040 p.

16 Žukas, J. V. Balnoja broliai žirgus. Lietuvos kavalerija (1918-1940 m.). Paskutinis raitosios kariuomenès etapas. Karys, 1991, Nr. 7, p. 7-9.

17 Rezmer, W. Kavaleria litewska 1918-1921. In Kavaleria przeciwników i sojuszników Wojska Polskiego w latach 1918-1921. Red. A. Smoliński. Toruń, 2003, s. 103-174.

18 Surgailis, G. Lietuvos kariuomene 1918-1998. Vilnius, 1998, p. 49.

19 Lesčius, V. Lietuvos kariuomenès aprūpinimas (1921-1940 m.). Karo archyvas, 2011, t. XXVI, p. 114-271.

20 Lesčius, V. Lietuvos kariuomenès organizavimo, dislokavimo ir ginkluotès pokyčiai 1938-1940 m. Karo archyvas, 2009, t. XXIV, p. 147-160.

21 Tamošiūnas, M. Lietuvos kariuomenés kavalerija 1919-1940 m.: tradicijos, kasdienybe, vizijos [baigiamasis bakalauro darbas, Kaunas, 2013], žr.: http://www.antraspasaulinis. net/e107_plugins/content/content.php?content.1243
} 
reikiamos medžiagos galima rasti Lietuvos centriniame valstybės archyve (LCVA). Šiame tyrime remiamasi dokumentais, saugomais Kavalerijos štabo (f. 1326), Kariuomenès štabo (f. 929), Šaulių sąjungos (f. 561) ir kituose fonduose. Tiriant tarpukario Lietuvos kavaleriją aktualūs publikuoti šaltiniai: Kavalerijos statutas (I ir II d.) ${ }^{22}$, Vyriausiojo kariuomenès štabo $^{23}$ ir Vytijos leidiniai ${ }^{24}$, taip pat išskirtini mjr. Izidoriaus Kraunaičio ${ }^{25}$, vyr. lnt. Juozo Žlabio ${ }^{26}$, gen. št. plk. ltn. Kazio Griniaus ${ }^{27}$, Aloyzo Valušio ${ }^{28}$, Juozo Lanskoronskio ${ }^{29}$ darbai. Be to, 1934 m. buvo išleista 1-ojo kavalerijos pulko istorija, kurioje aptariamas žirgo vaidmuo ir kavalerijos raida, raitų karinių dalinių kūrimosi Lietuvoje tarpukariu ypatumai ${ }^{30}$. Kaip šaltiniai, analizuojant Lietuvos kariuomenès kavaleriją tarpukariu, aktualūs ir kariniai periodiniai leidiniai: Mūsu žinynas, Karys, Kardas, Trimitas.

Atsižvelgiant ị minètas tarpukario Lietuvos kariuomenès rūšių ištirtumo aplinkybes šiame straipsnyje bus analizuojamos Lietuvos nereguliariụjų kariuomenès pajègų kūrimo XX a. 4-jame dešimtmetyje problemos. Nereguliarūs daliniai, arba aktyvusis rezervas, nebuvo naujas ar tik tarpukario Lietuvai būdingas reiškinys. Tokių dalinių yra ir XXI a. Lietuvos ginkluotosiose pajègose. Tai - Krašto apsaugos savanorių pajègos (KASP), kurių nariai save tapatina su Nepriklausomybės kovų savanoriais, $1941 \mathrm{~m}$. birželio sukilimo dalyviais ir pokario partizanais ${ }^{31}$. Tarpukario šaulių tra-

22 Kavalerijos statutas. I dalis. Vieno mokymas. Projektas. Kaunas, 1925, 75 p.; Kavalerijos statutas K-51. II dalis. Kautynes. Kaunas, 1938, 544 p.

23 Joju tarnyba: divizijos eskadronas ir mišri žvalgomoji rinktine. Kaunas, 1928, 135 p.

24 Arkliu priežiūros taisyklès. Kaunas, 1931, 26 p.; Lietuvos raiteliai iki Didžiojo karo (keletas istorinių bruožu). Kaunas, 1934, 40 p.

25 Kraunaitis, [I.] Mùsu kavalerijos organizavimas ir jos veikimas pirmame nepriklausomybès dešimtmetyje. Kaunas, 1928, 30 p.; Kraunaitis, [I.] Prancūzų kavalerija kautynėse. Mūsu žinynas, 1929, t. XVI, Nr. 49, p. 233-250; Kraunaitis, [I.] Kavalerijos taktika. Kaunas, $1932,152 \mathrm{p}$.

26 Žlabis, [J.] Kavalerijos žvalgybos organizacija mūsų ir kitų kariuomenių statutuose. Mūsų žinynas, 1929, t. XVII, Nr. 54, p. 129-144.

27 Grinius, [K.]. Kavalerijos lauko tarnybos pagrindai. Kaunas, 1930, 41 p.

28 Valušis, A. Modernines kavalerijos uždaviniai. Kaunas, 1937, 30 p.

29 Lanskoronskis, J. Kavalerija. Kaunas, 15 p.

30 Gusaras: 1-ojo gusaru Didžiojo Lietuvos etmono Jonušo Radvilos pulko 15 m. gyvavimo sukakčiai paminèti. Red. N. Gasènas. Kaunas, 1934, 97 p.

31 Auryla, J. et. al. Tẻvynès sargyboje. Krašto apsaugos savanorių pajëgu dvidešimtmečio 
dicijas tęsia atkurtoji Lietuvos šaulių sąjunga (LŠS). Taigi, gal galima kelti klausimą, ar tarpukariu Lietuvoje nebuvo jokių kitų karinių struktūrų, kurios pagal teritorinị formavimo ir tarnybos savanoriškumo principus būtų artimos KASP? Be to, šiame straipsnyje pirmiausia ieškoma atsakymo ị klausimus, susijusius su teritorinių dragūnų tarnybos formavimo tarpukario Lietuvoje priežastimis, t. y. kaip plačiai Europos kariuomenėse buvo paplitę kavalerijos daliniai ir kodèl Lietuva neatsisake šios palyginti brangios kariuomenès rūšies - kavalerijos, kokių būta bandymų kurti teritorinius kavalerijos dalinius, kol nebuvo teritorinių dragūnų tarnybos.

\section{Lietuvos kavalerija tarpukariu}

Anot J. V. Žuko, po Pirmojo pasaulinio karo Europos spaudoje „kilo daug ginčų dèl kavalerijos reikšmès ir tolesnio vaidmens būsimuose karuose. Išsiskyrė dvi nuomonès: vieni (daugiausiai Prancūzijos, Italijos, Lenkijos karo tyrejai) teige, kad kavaleriją reikia reorganizuoti ir apginklavus sunkiaisiais ginklais paversti raitaisiais pestininkais, kiti (Sov. Rusijos, Turkijos, Serbijos karybos specialistai), priešingai, manė, kad reikia stiprinti tradicines kavalerijos rūšis. Nepaisant visų ginčų, nẻ viena Europos valstybé neatsisake kavalerijos ir ịsijungè ị Antrąji pasaulinị karą didesnèmis ar mažesnèmis kavalerijos pajegomis, organizuotomis pagal tos šalies karinę doktrinąa ${ }^{{ }^{32} 2}$.

Po Lietuvos nepriklausomybès paskelbimo pradejus kurti kariuomenę, formuoti karinius dalinius, didžiąją dali pajègų sudare pèstininkai. Kitoms kariuomenès rūšims, tokioms kaip artilerija ir kavalerija, trūko ir karinių specialistų, ir techninių priemonių, ir tinkamų žirgų. 1919-1920 m. buvo suformuoti 3 kavalerijos pulkai (KP). 1920 m. pabaigoje juos sudare 10 eskadronų, juose tarnavo: 61 karininkas, 6 karo valdininkai, 3 gydytojai, 1839 kareiviai. Pulkai buvo ginkluoti 20 kulkosvai-

\footnotetext{
kronikos. 1991-2011. Vilnius, 2011, p. 7.

32 Žukas, J. V. Balnoja broliai žirgus. Lietuvos kavalerija (1918-1940 m.). Paskutinis raitosios kariuomenès etapas. Karys, 1991, Nr. 7, p. 7.
} 
džių, 1414 karabinų ir šautuvų, 617 kardų, turèjo 1001 balną, 1317 žirgų ir t. t. Pagal 1920 m. gruodžio 15 d. etatus trūko 49 karininkų, 12 karo valdininkų, 985 kareivių ir 1886 žirgų. Tuo metu 3 KP tarnavo 1909 kariai, t. y. 64,6\% numatytos etatinès sudèties, nes pagal etatus $3 \mathrm{KP}$ turèjo būti 2955 kariai. Juose tarnaujantys kavaleristai sudarè 4,2 \% kariuomenès, užèmus visus etatus, kavalerijos pulkuose būtų tarnavę 4,6\% visų karių ${ }^{33}$. Aptariamuoju laikotarpiu formaliai buvusiems 44 Lietuvos kariuomenès pèstininkų batalionams teko 10 kavalerijos eskadronų, taigi santykis - 4,4 su 1. Palyginus galima konstatuoti, kad, vykstant Nepriklausomybès kovoms, $1920 \mathrm{~m}$. balandi Lenkijos kariuomenèje fronte buvo 258 pėstininkų batalionai ir 108 kavalerijos eskadronai, o tų pačių metų rugsèji - jau 297 péstininkų batalionai ir 171 eskadronas $^{34}$. Taigi Lenkijos pajègose pėstininkų batalionų ir kavalerijos eskadronų santykis atitinkamai buvo 2,4 su 1 ir 1,7 su 1. Vadinasi, jos kavalerijos dalinių, palyginti su péstininkų dalinių skaičiumi, buvo apie du su puse karto daugiau negu Lietuvos kariuomenès. Verta pažymèti, kad XX a. pirmoje pusejje, vertinant ir lyginant karines pajègas, dažniausiai buvo skaičiuojami pėstininkų batalionai, kavalerijos eskadronai ir artilerijos baterijos, o ne pulkai, brigados ir divizijos.

Kavalerijos stygių Lietuvos kariuomenèje iliustruoja ir tai, kad 1920 m. rudeni prasidejus gen. Lucjano Żeligowskio pajègų puolimui Lietuvoje paskubomis buvo pradeti kurti dar du nauji KP - 2-asis ir 3-iasis - suvokiant, kad péstininkams kovoti su judriais kavalerijos daliniais sunku. Lenkijos pajègos 1920 m. spalio 9 d. užèmè Vilnių. Šis Lenkijos pajègų puolimas buvo sustabdytas per $1920 \mathrm{~m}$. lapkričio 19 d. Širvintų ir lapkričio 21 d. Giedraičių kautynes. Tačiau Lenkijos kavalerijos daliniai buvo prasiveržę ì Lietuvos pajègų užnugarị ir pasiekę net Jonavą. Karinès akcijos pradžioje gen. L. Żeligowskio pajègas sudarè apie 15500 karių (iš jų apie 7300 - karinèms operacijoms pasirengusių rikiuotès karių), ginkluotų 139 kulkosvaidžiais ir 44 artilerijos pabūklais ${ }^{35}$. Lenkijos istoriografinèje tradicijoje vadinamąją Vidurio Lietuvos kariuomenę sudarè 8 PP (22 batalionai), $3 \mathrm{KP}$ ir 1 batalionas, iš viso 14 raitelių, 2 kulkosvaidžių ir 1 technikos

\footnotetext{
33 Lesčius, V. Lietuvos kariuomene 1918-1920. Vilnius, 1998, p. 424-429.

34 Wyszczelski, L. Wojsko Polskie w latach 1918-1921. Warszawa, 2006, s. 81, 87.

35 Rezmer, W. Vidurio Lietuvos karinis potencialas. Darbai ir dienos, 2004, t. XL, p. 80-81.
} 
eskadronai, artilerijos daliniai ${ }^{36}$. Be to, šias pajėgas šiaurès rytuose dengè II Lenkijos armija, vadovaujama gen. Edwardo Rydzo-Śmigły‘o, o pietuose (nuo Rytprūsių iki Varẻnos) - III armija, vadovaujama gen. Władysławo Sikorskio. Iš viso abiejose armijose buvo apie 65000 rikiuotès karių (vadinamųų kardų ir durtuvų), o su L. Żeligowskio pajègomis - apie 73000. Tai, Lenkijos istoriko Waldemaro Rezmerio teigimu, buvo triuškinanti, keturguba, persvara, palyginti su Lietuvos Respublikos karinemis pajėgomis, kurias, pasak autoriaus, sudare daugiau kaip 17000 karių, be įvairių savanoriškų partizanų junginių, kurie efektyviai veikè etniškai lietuviškose teritorijose $^{37} .1920 \mathrm{~m}$. spalio $1 \mathrm{~d}$. Lietuvos kariuomeneje buvo 1416 karininkų, 1801 civilinis tarnautojas ir 31519 kareivių (iš viso 34736 žmonès) ${ }^{38}$.

I konfliktą, siekiant jị sureguliuoti, įsitraukus Tautų Sąjungai, o pagaliau ir gen. L. Żeligowskio pajègoms nepavykus per trumpą laiką pasiekti aiškios pergalès ir pradejus strigti aprūpinimui, prasidejus lenkų ir lietuvių broliavimuisi fronte, Lenkijos pajègos surengè paskutinị puolimą. Šioje karinèje operacijoje naujai suformuota kavalerijos brigada turèjo suvaidinti lemiamą vaidmenị - prasiveržti ị Lietuvos kariuomenės užnugarị, sukelti pavojų Kaunui ${ }^{39}$ ir nutraukti susisiekimą geležinkeliu Šiauliai-Kaunas ${ }^{40}$. Lenkijos kariuomenès Vilniaus kavalerijos brigada, vadovaujama papulkininkio Mścisławo Butkiewicziaus, veikė gana efektyviai ${ }^{41}$. Jos tikslas (brigadą sudare 11 eskadronų) buvo dezorganizuoti Lietuvos pajègas, greitai pasiekti Kauną, politiškai paveikti prolenkiškai nusiteikusius vietos gyventojus. Be to, būdama priešo užnugaryje (1 žemèlapis), brigada turejo sunaikinti infrastruktūrą ${ }^{42} .1920 \mathrm{~m}$. lapkričio $17 \mathrm{~d}$. ties Balninkais, Kurkliais ir Anykščiais prasiveržusi kavalerijos brigada

\footnotetext{
36 Michniewicz-Helman, M. Vilniaus kavalerijos brigados reidas Kèdainių kryptimi. Mūsų žinynas, 1926, t. X, Nr. 28, p. 48.

37 Rezmer, W. Vidurio Lietuvos karinis potencialas. Darbai ir dienos, 2004, t. XL, p. 80-81.

38 Lietuvos kariuomenès augimas. LCVA, f. 929, ap. 3, b. 617, 1. 18-18 apv. 1.

39 Lesčius, V. Lietuvos kariuomenè Nepriklausomybès kovose 1918-1920. Vilnius, 2004, p. 376-377.

40 Matusas, J. Lietuvos šaulių sajungos istorija. Sud. A. Liekis, Vilnius, 1992, p. 49.

41 Rezmer, W. Vidurio Lietuvos karinis potencialas. Darbai ir dienos, 2004, t. XL, p. 82.

42 Lesčius, V. Lietuvos kariuomenè Nepriklausomybès kovose 1918-1920. Vilnius, 2004, p. 394.
} 


\section{Lietuvos kariuomenės kovos su Lenkijos gen. Lucjano Żeligowskio pajègomis $1920 \mathrm{~m}$. pabaigoje}

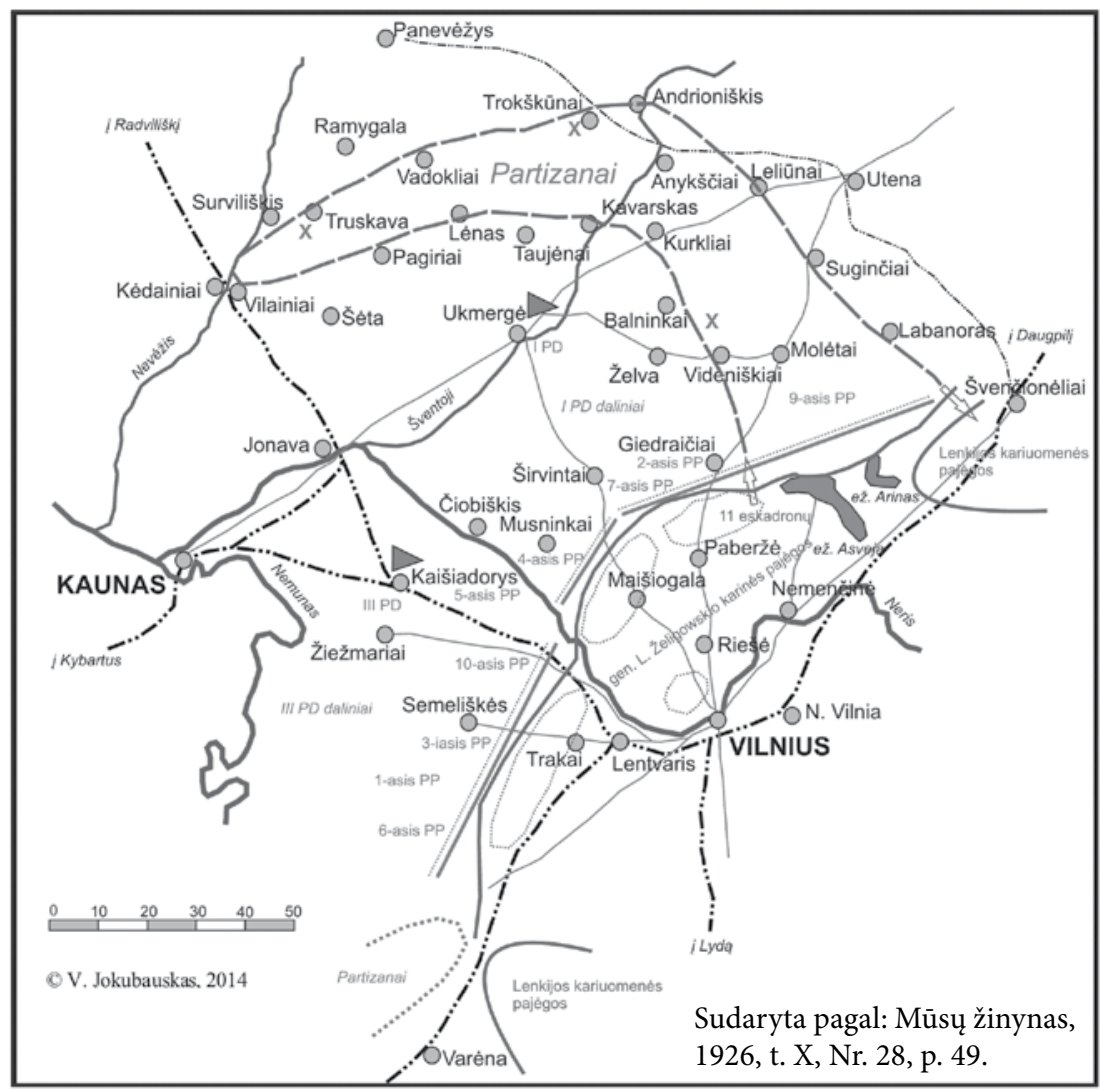

\section{Sutartiniai ženklai:}

Lietuvos kariuomenès PD štabų dislokacijos vietos

----- Lietuvos partizanų pozicijos

=-- Lietuvos kariuomenès pozicijos

X Pagrindinès šaulių - partizanų susirèmimų su Lenkijos kavalerijos daliniais vietos

Pagrindiniai keliai
...-.- Pagrindinès geležinkelių linijos Gen. L. Żeligowskio pajègų sutelkimo rajonai

- - Lenkijos kariuomenès (gen. L. Želigowskio) kavalerijos brigados reido ị Lietuvos pajègu užnugarị maršrutas

Lenkijos kariuomenès pozicijos 
jau tą pačią dieną ties Baltadvariu susišaudè su Alantos šaulių būriu ${ }^{43}$ ir apiplèše Kurklių miestelio gyventojus. Lietuvos kariuomenès I pėstininkų divizijos vadas plk. ltn. Edvardas Adamkavičius ir jo štabas galvojo, kaip sulaikyti Lenkijos kavalerijos puolimą. Tai buvo pavesta 8-ojo PP II ir III batalionams $^{44}$ ir 7-ojo PP Mokomajai kuopai ir I batalionui, kuris prieš Lenkijos ulonus veikė Kurklių rajone ${ }^{45}$. Kovojant su Lenkijos kavalerija aktyviai dalyvavo ir partizanai - šauliai. Sunkiausias uždavinys Panevėžio šaulių rinktinei teko 1920 m. lapkričio 19-24 d. kovojant su ịsiveržusia per frontą lenkų raitelių brigada. Pirmasis ginkluotas susidūrimas įvyko lapkričio $21 \mathrm{~d}$. Truskavos rajone ${ }^{46}$, čia su priešo kavalerija susikovė penki Ramygalos būrio partizanai - šauliai ${ }^{47}$. Paaiškejjus ịsiveržusios kavalerijos brigados žygio krypčiai, šaulių kuopos būrèsi Raguvos ir Troškūnų kryptimis. Keliuose susidūrimuose Lenkijos pajègos neteko keleto karių. Paskutinis ir didžiausias susiremimas ịvyko Troškūnų miestelyje lapkričio 22 d. ${ }^{48} 1920$ m. lapkričio 20-24 d. Lenkijos kavalerijos brigada, persekiojama partizanų - šaulių, ịveikè ilgą maršrutą, kurị sudarè: Videniškiai, Balninkai, Kurkliai, Kavarskas, Taujènai, Lènas, Pagiriai, šiauriau Šètos, Lančiūnava, Apytalaukis, Vilainiai, Gineitai, Surviliškis, Truskava, Vadokliai, Traupis, Troškūnai, Andrioniškis, Elmininkai, Rubikių ežeras, Leliūnai, Skudutiškis, Labanoras ${ }^{49}$ - ir 24 d. rytą, reido ì priešo užnugarị metu ịveikusi $250 \mathrm{~km}$ atstumą, Lietuvos kariuomenès užnugaryje užėmė Labanorą ir pasiekè už $10 \mathrm{~km}$ buvusius savo pèstininkų dalinius ${ }^{50}$. Iš viso Lietuvos pajėgu užnugaryje Lenkijos kariuomenès kavalerijos brigada

\footnotetext{
43 Matusas, J. Lietuvos šaulių sajungos istorija. Sud. A. Liekis, Vilnius, 1992, p. 49-50.

44 Lesčius, V. Lietuvos kariuomenè Nepriklausomybès kovose 1918-1920. Vilnius, 2004, p. 394.

457 pesst. Žemaičių Kunigaikščio Butegeidžio pulkas. Kartinis „Kario“ priedas. Kaunas, 1928 m. rugpjūčio 5 d., p. 2-7.

46 Petkevičius. Panevėžio rinktinè kovose. Trimitas, 1930, birželio 12, Nr. 24, p. 475-476.

47 Barauskas, B. Ramygala: atsiminimy siluetai [mašinraštis]. Palanga-Panevèžys, 1982, p. 21.

48 Petkevičius. Panevėžio rinktinè kovose. Trimitas, 1930, birželio 12, Nr. 24, p. 475-476.

49 Sabalys. Mūsų kariuomenès žygiai 1919-1920 metais. Trimitas, 1935, gruodžio 12, Nr. 50, p. 952.

50 Michniewicz-Helman, M. Vilniaus kavalerijos brigados reidas Kèdainių kryptimi. Mūsų žinynas, 1926, t. X, Nr. 28, p. 58.
} 
veikè 7,5 dienos. O Lietuvos kariuomenè, neturèdama atitinkamų kavalerijos pajėgų, neịstengè priešo brigados nei išsklaidyti, nei nuginkluoti ${ }^{51}$. Tai buvo patirtis, ị kurią Lietuvos kariuomené, objektyviai vertindama pajègų struktūrą ir pobūdị, negalèjo neatsižvelgti. Tarpukariu - 1933 m. Lietuvos kariuomenejje buvo išanalizuota padètis ir slapta konstatuota, kad Nepriklausomybės kovų laikotarpiu lietuviški kavalerijos daliniai formuojami vangiai. Tai lèmè: 1) kavalerijos karininkų stygius; 2) vadovybės požiūrio i̇ galimą kavalerijos naudojimą nebuvimas ir 3) materialiniai trūkumai. Todèl 1920 m. pabaigoje, Lenkijos kavalerijos brigadai ịsiveržus ị Lietuvos kariuomenès užnugarị, paaiškèjo, kad pėstininkai negali efektyviai veikti prieš kavaleriją, o vienintelio tuo metu buvusio KP eskadronai išskirstyti po pėstininkų divizijas (PD). Todèl skubiai buvo imtasi formuoti 2-ąji ir 3-iąji KP bei kavalerijos diviziją ${ }^{52}$. Pastarieji KP aktyviuose karo veiksmuose Nepriklausomybės kovų metu nedalyvavo, patirties kovos lauke igijo tik 1-asis $\mathrm{KP}^{53}$.

Nepriklausomybès kovų metu Lietuvos kariuomenè ịstengè sudaryti tik $3 \mathrm{KP}$, tačiau „pagerejus mūsų [Lietuvos - V. J.] politinei padéčiai ir nurimus užpuldinejjimams, dèl brangaus išlaikymo nuspręsta: vieną kavalerijos pulką išformuoti“, todèl 1924 m. 3-iasis dragūnų Geležinio Vilko pulkas buvo išformuotas ${ }^{54}$. Apskritai kuriant Lietuvos kariuomenès kavaleriją daug nusipelnė gen. ltn. Bronislovas Skomskis ${ }^{55}$. Visiems 3 pul-

\footnotetext{
51 Lesčius, V. Lietuvos kariuomenè Nepriklausomybès kovose 1918-1920. Vilnius, 2004, p. 399.

52 Kavalerijos perorganizavimo projektas, 1933 m. rugsejjo 16 d. LCVA, f. 1326, ap. 1, b. 163, 1. 206.

53 Plačiau apie 1-ojo KP kūrimąsi ir karinius veiksmus Nepriklausomybès kovų metu žr.: Gusaras: 1-ojo gusaru Didžiojo Lietuvos etmono Jonušo Radvilos pulko $15 \mathrm{~m}$. gyvavimo sukakčiai paminèti. Red. N. Gasėnas. Kaunas, 1934, p. 8-28.

54 Gudelevičius. 3 dragūnų Geležinio Vilko pulko metinę sukaktį minint. Kardas, 1936, rugsèjo 1, Nr. 17 (246), p. 457.

55 Jankauskas, V. Nepriklausomos Lietuvos generolai. Vilnius, 1998, p. 101-107.
} 
kams - 1-ajam $\mathrm{KP}^{56}, 2$-ajam $\mathrm{KP}^{57}$ ir 3-iajam $\mathrm{KP}^{58}$, - kurių dislokacijos vieta,

56 Pulko pavadinimas ir pavaldumas kito: nuo 1919 m. gegužès 12 d. iki 1919 m. spalio $24 \mathrm{~d}$. - 1-asis lietuvių raitelių pulkas; nuo $1919 \mathrm{~m}$. spalio $25 \mathrm{~d}$. iki $1921 \mathrm{~m}$. liepos $9 \mathrm{~d}$. 1-asis raitelių pulkas; nuo $1921 \mathrm{~m}$. liepos $10 \mathrm{~d}$. iki $1922 \mathrm{~m}$. kovo $31 \mathrm{~d}$. - 1-asis kavalerijos pulkas; nuo $1922 \mathrm{~m}$. balandžio $1 \mathrm{~d}$. iki $1927 \mathrm{~m}$. rugsèjo $24 \mathrm{~d}$. - 1-asis husarų pulkas; nuo 1927 m. rugsèjo 25 d. iki 1939 m. spalio 6 d. - 1-asis husarų Didžiojo Lietuvos etmono kunigaikščio Jonušo Radvilos pulkas; nuo 1939 m. spalio 7 d. iki 1940 m. liepos 24 d. 1-asis husarų kunigaikščio Jonušo Radvilos pulkas; nuo 1940 m. liepos 27 d. iki 1940 m. spalio 27 d. - 1-asis husarų pulkas. Nuo 1919 m. spalio 25 d. pulko vadas buvo pavaldus Generalinio štabo viršininkui, nuo 1920 m. lapkričio 28 d. - Armijos vadui, nuo $1921 \mathrm{~m}$. sausio 14 d. - I raitelių divizijos vadui, nuo $1921 \mathrm{~m}$. rugpjūčio $1 \mathrm{~d}$. - I kavalerijos divizijos vadui, nuo $1924 \mathrm{~m}$. sausio $1 \mathrm{~d}$. - Atskirosios kavalerijos brigados vadui ir II karo apygardos viršininkui, nuo $1925 \mathrm{~m}$. rugsèjo 5 d. - II karo apygardos viršininkui, nuo $1927 \mathrm{~m}$. birželio 15 d. - Kavalerijos inspektoriui ir II karo apygardos viršininkui, nuo 1927 m. liepos 5 d. - Kavalerijos viršininkui ir II karo apygardos viršininkui, nuo $1933 \mathrm{~m}$. vasario 18 d. - Kavalerijos viršininkui, nuo 1940 m. liepos 25 d. - II pèstininkų divizijos vadui. 1940 m. spalio 27 d. pulkas buvo išformuotas. [žr. 201408 20] http://eais-pub.archyvai.lt/ eais/faces/pages/forms/search/F3001.jspx

57 Pulko pavadinimas ir pavaldumas kito: nuo $1920 \mathrm{~m}$. spalio $30 \mathrm{~d}$. iki $1922 \mathrm{~m}$. kovo 31 d. - 2-asis raitelių pulkas; nuo $1922 \mathrm{~m}$. vasario 4 d. iki $1922 \mathrm{~m}$. kovo $31 \mathrm{~d}$. - 2-asis kavalerijos pulkas; nuo $1922 \mathrm{~m}$. balandžio $1 \mathrm{~d}$. iki $1928 \mathrm{~m}$. rugsèjo $29 \mathrm{~d}$. - 2-asis ulonu pulkas; nuo 1928 m. rugsèjo 30 d. iki 1940 m. liepos 24 d. - 2-asis ulonų Lietuvos didžiosios kunigaikštienès Birutès pulkas; nuo 1940 m. liepos 25 d. iki 1940 m. spalio 26 d. 2-asis ulonų pulkas. Tik ịkurtas pulkas buvo pavaldus Armijos vadui, nuo $1921 \mathrm{~m}$. sausio 14 d. - I raitelių divizijos, nuo 1921 m. rugpjūčio 1 d. - I kavalerijos divizijos vadams, nuo 1924 m. sausio 1 d. - Atskirosios kavalerijos brigados vadui ir III karo apygardos viršininkui, nuo 1925 m. birželio 6 d. - III karo apygardos viršininkui, nuo 1926 m. rugpjūčio 31 d. - II karo apygardos viršininkui, nuo 1927 m. birželio 15 d. - Kavalerijos inspektoriui ir II karo apygardos viršininkui, nuo 1933 m. vasario 18 d. - Kavalerijos viršininkui, nuo $1940 \mathrm{~m}$. liepos $25 \mathrm{~d}$. - III pèstininkų divizijos vadui. $1940 \mathrm{~m}$. spalio $26 \mathrm{~d}$. pulkas buvo išformuotas. [žr. 201408 20] http://eais-pub.archyvai.lt/eais/faces/pages/forms/search/ F3001.jspx

${ }^{58}$ Nuo 1920 m. spalio 1 d. iki 1920 m. spalio 31 d. buvo atskira raitelių šimtinè Geležinis Vilkas, nuo 1920 m. lapkričio 1 d. iki 1921 m. liepos 26 d. - 3-iasis raitelių Geležinio Vilko pulkas, nuo $1921 \mathrm{~m}$. liepos 27 d. iki 1922 m. kovo 31 d. - 3-iasis kavalerijos Geležinio Vilko pulkas, nuo $1922 \mathrm{~m}$. balandžio 1 d. iki $1924 \mathrm{~m}$. sausio $1 \mathrm{~d}$. - 3-iasis dragūnų Geležinio Vilko pulkas; 1924 m. sausio 1 d. pulkas buvo išformuotas, o 1924 m. gegužès 29 d. galutinai likviduotas. Nuo 1935 m. gegužès 1 d. iki 1936 m. birželio 3 d., pulką atkūrus, jo pavadinimas - 3-iasis kavalerijos pulkas, nuo 1936 m. birželio 4 d. iki $1940 \mathrm{~m}$. liepos 28 d. - 3-iasis dragūnų Geležinio Vilko pulkas, nuo 1940 m. liepos 29 d. iki 1940 m. spalio 8 d. - 3-iasis dragūnų pulkas. $1920 \mathrm{~m}$. naujai suformuotas pulkas buvo pavaldus I raitelių divizijos vadui, nuo $1921 \mathrm{~m}$. liepos $27 \mathrm{~d}$. - I raitelių divizijos, nuo $1921 \mathrm{~m}$. 
pavadinimai ir pavaldumas kito, buvo suteikti tradicinès kavalerijos rūšių pavadinimai: husarai, ulonai ir dragūnai, nors tai buvo tik kavalerijos tradicijų tąsos, o ne struktūros, ginkluotès ar taktikos klausimas.

1926 m. Lietuvos kariuomeneje buvo 2 KP ir atskiras Mokomasis eskadronas. Kiekvieną KP sudare 4 kardų ir 1 kulkosvaidžių eskadronai, ryšių (1 radijo ryšio stotis), technikos, ūkio ir muzikantų komandos. Pagal etatus pulke turejjo būti 1059 kariai (iš jų 41 - karininkas) ir 1000 žirgų, o eskadrone - 43 kariai (iš jų 5 - karininkai) ir 156 žirgai, tačiau faktiškai kavalerijoje apie $1 / 4$ personalo buvo mažiau, negu numatyta ${ }^{59} \cdot 1$-asis KP buvo dislokuotas Kaune, 2-asis - Alytuje, o Mokomasis eskadronas - Marijampolejje $e^{60}$. Tuomečio Vyriausiojo štabo viršininko gen. št. plk. ltn. Kazio Škirpos teigimu, „kavalerijos organizacija visai pasenus. Ji yra daugiau panaši ị prieškarinę, o ne ị tai, ką mes dabar matome Europos valstybėse" ${ }^{\text {"61 }}$.

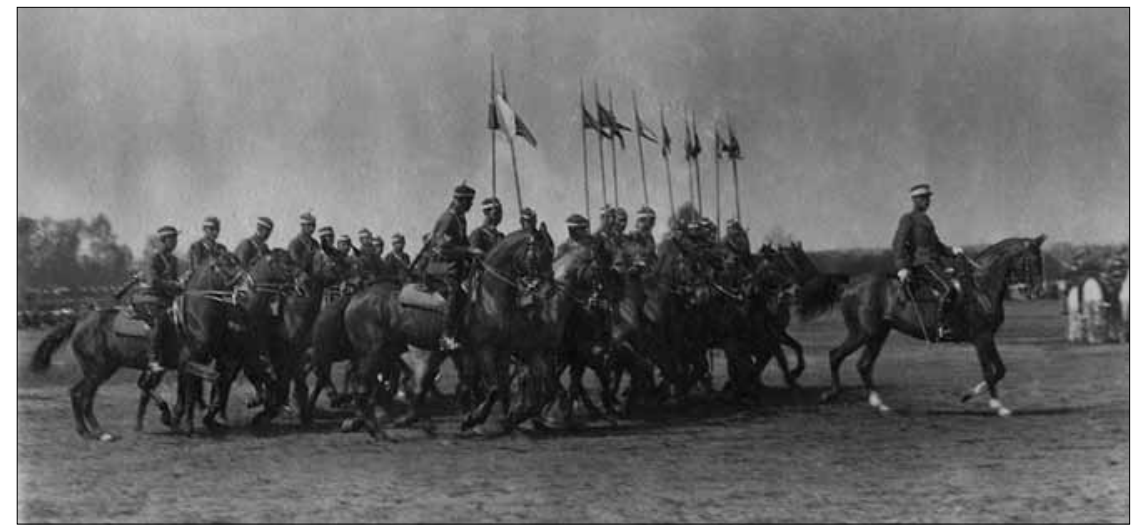

Lietuvos kariuomenės 1-ojo husarų pulko kariai parado Baltijos šalių karininkų apsilankymo Lietuvoje proga 1924 m. gegužès 14-18 d. metu (LCVA)

rugpjūčio 1 d. - I kavalerijos divizijos vadams. $1935 \mathrm{~m}$. atkurtas pulkas buvo pavaldus Kavalerijos viršininkui, nuo 1940 m. liepos 29 d. - I pėstininkų divizijos vadui. $1940 \mathrm{~m}$. spalio 8 d. pulkas buvo išformuotas. [žr. 201408 20] http://eais-pub.archyvai.lt/eais/faces/ pages/forms/search/F3001.jspx

59 Vyriausiojo štabo viršininko 1926 m. liepos 27 d. raportas. LCVA, f. 929, ap. 3, b. 536, 1. 4.

60 Samprotavimai apie Lietuvos Respublikos ginkluotụjų pajègų organizaciją ir krašto gynimą, 1926 m. liepos 27 d. LCVA, f. 929, ap. 3, b. 536, 1. 162.

61 Vyriausiojo štabo viršininko 1926 m. liepos 27 d. raportas. LCVA, f. 929, ap. 3, b. 536, 1. 9. 
Tarpukariu Lietuvos kariuomenès sudètyje ${ }^{62}$, priešingai nei Latvijos ir Estijos, kur buvo tik po $1 \mathrm{KP}$, jau taikos metu skirtingu laiku buvo sudaryti 2 ar 3 KP. Jų sudetis ir dydis kito: $1920 \mathrm{~m}$. buvo apie 900-1 000, $1926 \mathrm{~m}$. pabaigoje - apie 1100 , po $1927 \mathrm{~m}$. reformų - apie 900, o nuo $1935 \mathrm{~m}$. turejjo būti apie 1300 karių ${ }^{63} .1938 \mathrm{~m}$. sausio $1 \mathrm{~d}$. kavalerijoje tarnavo 141 karininkas, 2586 kareiviai, 48 tarnautojai ir 41 auklètinis, daliniai turejo 2410 žirgų. Pagal nustatytus karo meto etatus kiekviename mobilizuotame KP XX a. 4-ojo dešimtmečio pabaigoje turejjo būti 55 karininkai, 1326 kariai ir 1269 žirgai, raitosios artilerijos baterijose - po 5 karininkus ir 164 kareivius, 213 žirgų $^{64} .1940 \mathrm{~m}$. birželio $1 \mathrm{~d}$. kavalerijoje ir jai priskirtuose daliniuose tarnavo 3305 kariai (iš jų 151 - karininkas): Kavalerijos štabe - 13, 1 -ajame KP - 1 021, 2-ajame KP - 888, 3-iajame KP - 1 046, 1-ojoje raitosios artilerijos baterijoje - 107, 2-ojoje baterijoje - 110, 3-iojoje baterijoje - 103, remonto eskadrone - 17 karių $^{65} .1939 \mathrm{~m}$. Lietuvos kariuomenès vadovybès skaičiavimais, taikos meto kavalerijos karių skaičius - 3485 mobilizacijos atveju turejjo padidèti 2,4 karto, t. y. iki $8201^{66}$. Tokiu atveju ị kavalerijos dalinius būtų reikèję mobilizuoti apie 4700 karių. Žinoma, dauguma būtų buvę paskirti ị 5 formuojamas divizijų lengvąsias rinktines (pagal etatus visoms penkioms DLR būtų reikèję 2860 karių). 1940 m. rezervą sudare 171 kavalerijos karininkas ir 10762 parengti pirmos rūšies (iki 35 m.) kavalerijos atsargos kariai ${ }^{67}$. Galima konstatuoti, kad 1926 m. rezervą sudarè 69 kavalerijos karininkai ir 3175 kareiviai $^{68}$. Taigi per $14 \mathrm{~m}$.

\footnotetext{
62 Plačiau apie Lietuvos kariuomenės kavalerijos dalinius žr.: Statkus, V. Lietuvos ginkluotos pajegos 1918-1940 m. Chicago, 1986, p. 140-174.

63 Žukas, J. V. Balnoja broliai žirgus. Lietuvos kavalerija (1918-1940 m.). Paskutinis raitosios kariuomenès etapas. Karys, 1991, Nr. 7, p. 8.

64 Lesčius, V. Lietuvos kariuomenès organizavimo, dislokavimo ir ginkluotès pokyčiai 1938-1940 m. Karo archyvas, 2009, t. XXIV, p. 149, 158.

65 Knezys, S. Lietuvos kariuomenès inkorporavimas ị Raudonosios armijos sudètị. 29-jo šaulių teritorinio korpuso formavimas (1940 m. birželio 15 d. - 1940 m. gruodžio 31 d.). Lietuvos archyvai. Apie Lietuvos kariuomenę, 1999, t. XII, p. 119.

66 Vaičenonis, J. Lietuvos kariuomenès modernizacija (1926-1939). Darbai ir dienos, 2000, t. XXI, p. 170.

67 Jokubauskas, V. „Mažuju kariuomeniu““ galia. Tarpukario Lietuvos atvejis. Klaipėda, 2014, p. 574.

68 Vyriausiojo štabo viršininko 1926 m. liepos 27 d. raportas. LCVA, f. 929, ap. 3, b. 536, 1. 13 .
} 
kavalerijos rezervo karininkų skaičius padidejjo 2,5 karto, o kareivių - daugiau kaip 3 kartus. Formaliai XX a. 4-ojo dešimtmečio pabaigoje parengtas kavalerijos daliniu rezervas buvo pakankamas, tik dalis jo karių tarnybą buvo baigę prieš keletą ar net keliolika metų. Numatytas skaičius atsargos karių periodiškai buvo kviečiami ị pakartotinius mokymus kariuomenèje.

$\mathrm{XX}$ a. 4-ojo dešimtmečio pirmoje pusëje Lietuvos kavaleriją sudarè 2 KP, kurie, palyginti su Lenkijos pajegomis, nebuvo visaverte KB. Todèl $1933 \mathrm{~m}$. buvo parengtas kavalerijos reorganizavimo projektas, jame pasiūlyta ịsteigti 3-iajji KP, raitosios artilerijos grupę, pionierių eskadroną ir ryšių rinktinę ir per $5 \mathrm{~m}$. suformuoti visavertę kovinę KB. O tolesnèje ateityje imtis ir antrosios teritorines kavalerijos brigados formavimo, nes "tada, galima sakyti, būtumème pasiekę mūsų [Lietuvos - V. J.] sąlygoms idealaus kautynių kavalerijos sutvarkymo“. Projekte svarstyta, kad 3 raitosios artilerijos baterijoms apginkluoti tinka 76,2 $\mathrm{mm}, 75 \mathrm{~mm}$ arba $83,8 \mathrm{~mm}$ lauko artilerijos patrankos, kaip lengviausios, nes vokiški $77 \mathrm{~mm}$ pabūklai yra sunkesni. Samprotauta, kad tokia brigada galètu pasirengti veikti per 6 val., išvardytos ir tokio junginio naudojimo galimybès: 1) dengti mobilizaciją pagrindine priešo ịsiveržimo kryptimi; 2) apsaugoti mobilizuotų Lietuvos pajėgų sparną; 3) kadangi tai judrus kariuomenès rezervas, padidètu „priedangos, saugos, kautynių pasisekimo išnaudojimo ir nepasisekimo sumažejimo galimybès“. O iki tol buvusi kavalerija įvertinta kritiškai: „[M] ūsų kavalerija, tokiam stovyje, kaip ji yra dabar, savystoviems uždaviniams vykdyti negali būti pavartota, jos strateginè vertè yra begaliniai maža." ${ }^{69}$

XX a. 4-ajame dešimtmetyje po $1927 \mathrm{~m}$. reformų Lietuvos kariuomenès KP sudare 4 kardų, sunkiụjų kulkosvaidžių, mokomasis, ūkio ir technikos eskadronai, muzikantų komanda. 1935 m. Lietuvos kavalerija vèl buvo reorganizuota ir perginkluota, kiekvienam pulkui buvo priskirti šarvuočių (2 Landsverk 181-29/34 šarvuočiai) ir dviratininkų būriai. Sunkiųjų kulkosvaidžių eskadronai buvo papildyti automatinių pabūklų būriu ${ }^{70}$. Ilgą laiką taikos metu 1-asis husarų Didžiojo Lietuvos etmono K. J. Radvilos

\footnotetext{
69 Kavalerijos perorganizavimo projektas, 1933 m. rugsejo 16 d. LCVA, f. 1326, ap. 1, b. $163,1.206-214$.

70 Plačiau apie KP struktūros pokyčius žr.: Žukas, J. V. Balnoja broliai žirgus. Lietuvos kavalerija (1918-1940 m.). Paskutinis raitosios kariuomenès etapas. Karys, 1991, Nr. 7, p. 8.
} 
KP stovejo Kaune, 2-asis ulonų Didžiosios Lietuvos kunigaikštienès Birutės KP - Alytuje, atkurtas 3-iasis dragūnų Geležinio Vilko KP - Tauragèje, remonto eskadronas - Alytuje, kavalerijos viršininkas buvo ịsikūręs Kaune $^{71} .1935 \mathrm{~m}$. buvo suformuota raitosios artilerijos grupe iš 3 bateriju po $476,2 \mathrm{~mm}$ patrankas, po 1 bateriją kiekvienam $\mathrm{KP}^{72}$. Baterijos nebuvo visiškai sukomplektuotos, nors pagal taikos meto etatus jose turejo būti po 100 karių, 1939 m. rugpjūčio $1 \mathrm{~d}$. 2-ojoje tarnavo tik 71 karys $^{73} .1940 \mathrm{~m}$. planuota mobilizacijos atveju 2-ąją tankų kuopą reorganizuoti i 5 tanku būrius (po 3 VCL tankus)DLR sustiprinti, o 3 VCL tankus perkelti ị Mokomąją kuopą ${ }^{74}$. Taigi karo metu XX a. 4-ojo dešimtmečio pabaigoje Lietuvos kavalerija būtų prilygusi Lenkijos kariuomenès kavalerijos brigadai.

1928 m. pagal karo meto etatus PD turejjo sudaryti 11317 karių, 3773 žirgai, 1509 vežimai, 22 motorizuotosios transporto priemonès, divizijos sudètyje buvo numatytas 1 kavalerijos eskadronas ${ }^{75}$. Būtent $1928 \mathrm{~m}$. Vyriausiasis kariuomenès štabas išleido specialų leidinį, kuriame buvo išsamiai aptartos kavalerijos veikimo divizijos sudètyje galimybès ${ }^{76} .1934 \mathrm{~m}$. PD turèjo sudaryti 13789 kariai, o numačius formuoti divizijų lengvąsias kavalerijos rinktines (DLR, 572 kariai) - 456 karininkai ir 14229 karei-

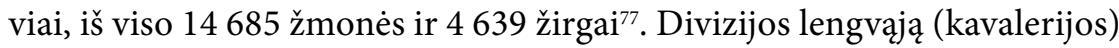
rinktinę (DLR) turejjo sudaryti štabas, 2 kardų eskadronai (kiekvienas po 4 kardų būrius ir 1 „padedamąjị būrị), dviratininkų būrys, sunkiụjų kul-

\footnotetext{
71 Vaičenonis, J. Lietuvos kariuomenè valstybès politinio gyvenimo verpetuose (19271940). Vilnius, 2004, p. 21.

72 Statkus, V. Lietuvos ginkluotos pajégos 1918-1940 m. Chicago, 1986, p. 900-911.

73 Lesčius, V. Lietuvos kariuomenès organizavimo, dislokavimo ir ginkluotès pokyčiai 1938-1940 m. Karo archyvas, 2009, t. XXIV, p. 157-158.

74 ŠR 1940 m. sausio 23 d. raportas ir priedai. LCVA, f. 828, ap. 1, b. 230, 1. 30.

75 Divizijos būstinè - 113, PP - 2770 ( 3 PP - 8310), AP (3 grupès po 2 baterijas) - 1308 , divizijos eskadronas - 167, ryšių kuopa - 205, pionierių kuopa - 296 kariai. Tarnybos: pėstininkų amunicijos kolona - 203, artilerijos amunicijos kolona - 69, inžinerijos kolona - 72, transporto kuopa - 212, tvarstomasis būrys - 46, karo lauko ligoninè - 90, darbininkų kuopa - 150, automobilių būrys - 76 kariai: Karo meto péstininkų divizijos sudètis, 1928 m. birželio 15 d. LCVA, f. 929, ap. 5, b. 264, 1. 67.

76 Joju tarnyba: divizijos eskadronas ir mišri žvalgomoji rinktine. Kaunas, 1928, p. 1-135.

77 Divizija turèjo turèti: 1493 įvairius vežimus, 12 keleivinių, 27 krovininius ir 5 sanitarinius automobilius, 20 motociklų, 74 dviračius, 77 lauko virtuves: PD karo meto sudètis, 1934 m. LCVA, f. 929, ap. 5, b. 410, 1. 4.
} 
kosvaidžių būrys, ryšių būrys ir „padedamasis“ būrys ${ }^{78}$. XX a. 4-ojo dešimtmečio pabaigoje didžiąją dali mobilizuotų Lietuvos pajègų turẻjo sudaryti pèstininkai, net 57,18 \%, artilerija - 9,17 \%, kavalerija (įskaitant divizijų DLR) - 6,54 \% ${ }^{79}$. Latvijos ir Estijos kariuomenèse kavalerijos dalis ir karių skaičius buvo gerokai mažesnis: Latvijos - 2 \% (3 189), Estijos - 3 \% $(3052)^{80}$. Tarpukariu teigta, kad aptariamuoju laikotarpiu apie $20 \%$ SSRS ir Lenkijos kariuomenių sudare kavalerija ${ }^{81}$. Tai, žinoma, gerokai padidintas istoriografijos nepatvirtintas skaičius.

Buvo apskaičiuota, kad kavalerija per 3 val. gali ịveikti $30 \mathrm{~km}$ atstumą, o per dieną - apie $100 \mathrm{~km}$ ir ị mūši stoti pèsčia. XX a. pirmojoje pusèje Vidurio ir Rytų Europos regione, kur plentų tinklas buvo menkai išplètotas ir plytėjo milžiniški miškų ir pelkių masyvai, kavalerija vis dar buvo naudojama. Bet kokiu metų laiku ir bet kokiomis vietovès sąlygomis ji galejjo gana lengvai įveikti didelius atstumus. Pavyzdžiui, 1932 m. 400 Lietuvos kariuomenés kavaleristų, imituodami kovos veiksmų situaciją, nužygiavo $960 \mathrm{~km}$ - per dieną vidutiniškai $73 \mathrm{~km}$, o žvalgybos daliniai $110-115$ km. 1938 m. rudens manevrų metu KP per 20 val. įveikè 93 km, o žvalgai - $130 \mathrm{~km}^{82} .1936 \mathrm{~m}$. balandị SSRS Raudonosios armijos $2 \mathrm{KP}$ atliko mokomąji žygị iš Smolensko ị Gomelį, vienas pulkas per 8 dienas nužygiavo $452 \mathrm{~km}$, per dieną vidutiniškai - 56,3 km, judèdamas $7 \mathrm{~km} / \mathrm{val}$. greičiu, o kitas - $427 \mathrm{~km}$, per dieną vidutiniškai pasistūmėdamas $58,4 \mathrm{~km}^{83}$.

Tačiau 1934 m. buvo konstatuota, kad Lietuvos kariuomenè neturi né vieno judraus artilerijos dalinio, todèl ir kavalerija karo atveju negali sudaryti visaverčio atitinkamos ugnies galios junginio. Siūlyta sudaryti atskirą raitosios artilerijos grupę ${ }^{84}$. Po visuotinès mobilizacijos Lietuvos kariuomenès kavaleriją turèjo sudaryti $3 \mathrm{KP}, 3$ atsargos kavalerijos eskadronai

\footnotetext{
78 Statkus, V. Lietuvos ginkluotos pajegos 1918-1940 m. Chicago, 1986, p. 158.

79 Vaičenonis, J. Lietuvos kariuomenès modernizacija (1926-1939). Darbai ir dienos, 2000, t. XXI, p. 170.

80 Salo, U. Eesti kaitseväe valmisolek sõjaks ja vastupanuvõimalused 1939. aastal. [magistro baigiamasis darbas]. Tartu, 2005, 1. 275.

81 Žukauskas, J. Lietuvos kariuomene. Kaunas, 1938, p. 13.

82 Ten pat, p. 173.

83 SSSR: kavalerijos žygis iš Smolensko ị Gomelị. Mūsų žinynas, 1936, t. XXXI, Nr. 141, p. 559.

84 Raitosios artilerijos sudarymo galimybès [1934 m.]. LCVA, f. 1326, ap. 1, b. 184, 1. 40.
} 
ir 5 DLR, o teritoriniai dragūnai pagal mobilizacijos planus turèjo būti ittraukti ị DLR sudetį. Paraduose ir parodomuosiuose mokymuose naudoti kardai ir pikès (ietys) nebuvo pagrindiniai ginklai, su kuriais kavaleristai galejo stoti ị tikrą mūšị. Iš esmès kavalerija buvo mokoma kautis pèsčiomis, kaip pėstininkai, o žirgai buvo tik transporto priemonė dideliems atstumams greitai ịveikti. Kavalerija, esant menkai motorizacijai ir prastai kelių sistemai, iš esmès buvo skirta žvalgybai atlikti, sparnams dengti ir greitai reaguoti ị kovos veiksmus, pasiuntus ją i pavojingus ruožus.

Karo atveju buvo galima tikètis Lenkijos kariuomenès kavalerijos prasiveržimo ị savųjų pajègų užnugarị - reido. Tokị reidą turejo atlikti strateginè kavalerija, pavaldi fronto arba kariuomenès vadui. Reidui surengti galèjo būti panaudota KD arba sustiprinta KB, sudaryta iš apie 2000 kardų, 80 sunkiųju ir 100 lengvųjų kulkosvaidžių, 18-24 artilerijos pabūklų. Reido tikslai galëjo būti šie: užimti ir išlaikyti svarbius punktus arba rajonus; ardyti priešo susisiekimo kelius; atitraukti rezervus; savosioms pajègoms traukiantis i priešo užnugarị, puolančių priešo pajègų aprūpinimui trikdyti. Reido metu kavalerija iš esmès turẻjo apsirūpinti pati, naudodama vietos išteklius ${ }^{85}$.

Tam tikra prasme Lietuvos kariuomenès motorizacijos lygis nebuvo itin aukštas, nes pagrindinè traukos jèga tebebuvo žirgai. Menką pajègu motorizacijos lygi galima pateisinti keletu priežasčių: 1) arkliais, priešingai nei motorizuotosiomis transporto priemonėmis, Lietuvos kariuomené galejo apsirūpinti savo krašte ir taip kompensuoti patirtus nuostolius; 2) pašaro arkliams taip pat buvo vietoje, o automobiliai priklausè nuo importinių degalų; 3) dèl prastos būklès dalis kelių rudeninio ir pavasarinio polaidžio metu tapdavo automobiliais neišvažiuojami, o arkliais kavalerija galejo įveikti didelius nuotolius miškais ir laukais, kur išvis jų nebuvo, ir netikètai užpulti priešą, taigi, motorizuotųjų pajègų judejjimas priklausè nuo kelių tinklo ir pravažumo, bet Lietuvos keliais net dviratininkams buvo sunku judèti; 4) buvo būtina turèti gausias kavalerijos pajègas, kurios sparnuose galètų judriai veikti prieš eventualaus priešo - Lenkijos - kavalerijos brigadas; 5) kariuomenę motorizuoti brangiai kainavo ${ }^{86}$.

${ }^{85}$ Sn. Kavalerijos veiksmai per reidą (lenkų pažiūros). Mūsų žinynas, 1937, t. Nr. 11, p. $618-620$.

86 Jokubauskas, V. „Mažuju kariuomenių“ galia. Tarpukario Lietuvos atvejis. Klaipèda, 2014, p. 196-197, 249, 257-259. 
Tarpukariu kavalerija tradiciškai laikyta manevringa, judria, lanksčia, netikètai veikiančia jèga, o moderniosios kavalerijos šios savybès tapo net ryškesnès, be to, išaugo jos ugnies galia. Judrumas priklausė nuo žygio greičio ir veiksmų rajono, raiteliai judèdavo dvigubai greičiau negu pėstininkai ir kautynių lauką galejo pasiekti vidutiniu 7 km/val. greičiu. Kadangi kavalerijos daliniai tiek dieną, tiek naktị gali judèti tuo pačiu greičiu, tai per 24 val. pajègūs įveikti $100 \mathrm{~km}$, o per 2 paras $-160 \mathrm{~km}$. O dèl judrumo ir ugnies galios sinergijos jų veiksmai neretai būdavo taktiškai (dèl žygio greičio) ir strategiškai (dèl ištvermingumo) netikèti. Lankstumas - išskirtinè kavalerijos savybe் - tai gebejimas ịvairiuose karo teatruose sparčiai keisti rikiuotę iš plačios i gilią ir, atvirkščiai, ịveikti arba apeiti bet kokias kliūtis, ị mūšio lauką greitai atvykti su visomis priskirtomis kautynių priemonėmis, manevruoti, kol neprasidejo artimoji kova. Veikiant judriai ir lanksčiai buvo galima pasiekti netikètumo efektą. Vis geriau kavalerijos dalinius aprūpinant automatiniais ginklais ir artilerijos priemonemis, augo šios kariuomenès rūšies ugnies galia ${ }^{87}$.

1938 m. Kavalerijos statute rašoma, kad „kavalerija yra kariuomenès ginklų rūšis, galinga savo paslankumu ir ugnimi, galinti kautis bet kurioje vietoje ir bet kuriuo laiku. <...> ugnies galingumas priklauso nuo automatinių ginklų skaičiaus. <...> Kavalerijos ginklai yra šie: kardas, karabinas bei šautuvas su durtuvu, lengvasis kulkosvaidis, sunkusis kulkosvaidis, automatinis pabūklas, pistoletas, rankinè granata, šautuvinė granata. Kai kada priskiriami minosvaidžiai. <..> karabinas ir šautuvas yra pagrindinis asmeninis raitininko ginklas. $<\ldots>$ Kardas - asmeninis raitininko ginklas. Prityrusioje ir miklioje rankoje jis yra lemiamos vertès ginklas raitųjų atakoje ir visur ten, kur aplinkybès neleidžia greitai bei patogiai pavartoti šaunamojo ginklo. <...> Lengvasis kulkosvaidis yra pagrindinis šaulių skyriaus ginklas $<\ldots . .>^{“ 88}$.

Kavalerijos atakos sparnuose turejjo būti remiamos intensyvia sunkiosios ginkluotės ugnimi, o raitelių ataka vykdoma tik išskirtiniais atvejais, esant palankioms aplinkybėms, nedideliais daliniais (iki eskadrono). Tokių atakų galëjo pasitaikyti žvalgybos, persekiojimo ar priedangos metu netikètai užklupus žygiuojantị, besiilsintị, besitraukiantị arba labai išvar-

87 Kraunaitis, [I.] Kavalerijos taktika. Kaunas, 1932, p. 1, 4-6.

${ }^{88}$ Kavalerijos statutas K-51. II dalis. Kautynès. Kaunas, 1938, p. 5, 15, 21, 23. 
gintą priešą ${ }^{89} .1936 \mathrm{~m}$. rudenị didžiųjų kariuomenès manevrų metu dèl netinkamo karininkų spendimo ịsitikinta, kad raiteliams atakuoti įsitvirtinusius pėstininkus būtų pražūtinga. Be to, klaidingu laikytas ir sprendimas kavalerijai atakuoti pėstininkus naudojant tankus, nes pastarieji buvo naudojami žvalgybai arba puolimui atlikti, kai priešas tam nepasiruošęs. Todèl karinè vadovybė konstatavo, kad toks taktinis sprendimas netinkamas - kavaleriją naudoti karo metu buvo uždrausta ${ }^{90}$.

Kavalerija buvo brangi, sunkiai per ilgą laiką sukuriama kariuomenès rūšis, todèl ją reikejjo tausoti. Pasak Lietuvos kavalerijos karininko, Prancūzijos Saint-Cyro ir Somiuro karo mokyklų absolvento, buvusio Kavalerijos štabo viršininko ir KP vado gen. št. plk. I. Kraunaičio, kavaleriją galima naudoti: 1) priedangai, kai reikia laiko papildomoms pajègoms - pėstininkams - atvykti; 2) žvalgybai, siekiant sužinoti priešo sumanymus ir manevro kryptị; 3) gynybai, siekiant sulaikyti priešo judejjimą; 4) puolimui, kai yra galimybė manevruoti; 5) sẻkmei išnaudoti, kai priešas traukiasi ir jo atsitraukimas virsta bėgimu ${ }^{91}$. Panašias mintis apie kavalerijos, kaip judrios ir ugnies galia pasižyminčios kariuomenès rūšies, naudojimą išdèstė ir gen. št. plk. A. Valušis, didelę reikšmę teikęs kavalerijos motorizacijai. Jis pažymėjo, kad pagal „senąji kavalerijos rūšių apibūdinimą“ judrieji ir greitieji husarai tinkami žvalgybai ir pasaloms rengti, o gausiai ugnies priemonėmis aprūpinti dragūnai (motorizuotieji šauliai, lydimi galingų ugnies priemonių) - priešakinių pozicijų punktams užimti ir išlaikyti, kirasyrai (šarvuočių junginiai ir puolamoji aviacija) - lemiamiems smūgiams suduoti. Apibendrindamas, kad „ateityje aviacijos ir motomechanizuotos divizijos išpildys savarankios moderninès kavalerijos uždavinius, mažesni vienetai - kariuomenès junginių kavalerijos. Betgi ten, kur vietovė mažai palanki (dideli plotai miškų, balų, daug upių, kelių tinklo būkle ir kita), reikès ir ateityje turèti raitosios kavalerijos junginius ir kavalerijos dalinius kariuomenès junginiams (pėst. divizijoms)“ [tekste išskirta autoriaus V. J. $]^{92}$. Taigi išpranašavo kavalerijos dalinių motorizaciją ir mechanizaciją,

\footnotetext{
89 Ten pat, p. 184-192.

90 „Raudonųjų“ II PD įvykusių $1936 \mathrm{~m}$. kariuomenès manevrų pastabos, $1936 \mathrm{~m}$. spalio 14 d. LCVA, f. 929, ap. 3, b. 907, 1. 118.

91 Kraunaitis, [I.] Kavalerijos taktika. Kaunas, 1932, p. 6-8.

92 Valušis, A. Moderninès kavalerijos uždaviniai. Kaunas, 1937, p. 9.
} 
kita vertus, poreikị tam tikromis gamtinèmis sąlygomis, kurios būdingos Lietuvai ir kitoms kaimyninėms šalims, išlaikyti ir tradicinès kavalerijos (su žirgais) dalinius.

1940 m. svarstant kavalerijos reorganizacijos klausimą, remiantis Kariuomenès štabo I skyriaus nuomone, padaryta išvada, kad Lietuvos kavalerija netinka moderniam karui, todèl būtina keisti jos taktiką, organizaciją ir ginkluotę. Pasiūlyta esamus KP reorganizuoti ị „kliūčių - užvartų

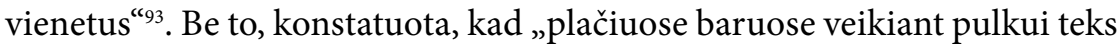
suskilti ị savarankiškai veikiančius eskadronus. Šiandien sunku ịsivaizduoti savarankiškai veikiantị eskadroną, kuris neturètų bent poros s. k., bent vieno ŠAP, o kur veikia ŠAP, ten turi būti bent mažas pionierių dalinys, nes ŠAP principe turi būti statomas už paruoštos kliūties, kuri priešo šarvuotị bent laikinai pristabdo ir tuo pačiu padidina ŠAP ugnies sèkmingumą "94.

2-ojo KP 3-iojo eskadrono vadas gen. št. kpt. Bronius Michelevičius pabrèžè, kad jau pirmosiomis karo valandomis Lietuvos kariuomenė susidurtų su judriomis priešo pajègomis, o žinant „krašto supimo koeficientą, t. y. mūsų [Lietuvos - V. J.] sienų ilgio santykị su mūsų teritorijos plotu“, ir Lietuvos kariuomenés pajẻgumus, aišku, jog ginti visų sienų ištisai bus nei̇manoma. Todèl, atsižvelgiant ị Lietuvos sąlygas, rekomenduota turèti negausias kavalerijos pajègas, aprūpintas motorizuotosiomis priemonėmis, kurios būtų judrios, lanksčios ir kaunančios galinga ugnimi ${ }^{95}$. Karo atveju planuotos mobilizuoti DLR pirmiausia turètų būti naudojamos priedangoje - stabdymui, o veikiant su divizija: a) žvalgybai; b) sparnų apsaugai; c) kaip judrus divizijos vado rezervas, todèl siūlyta keisti DLR struktūrą mažinant kardų būrių ir didinat ugnies vienetų skaičių ${ }^{96} .1940$ m. rengiantis kavalerijos reorganizacijai, brg. gen. Kazio Tallat-Kelpšos siūlymu buvo numatyta didinti KP ginklų skaičių: ịtraukti po 27 iki tol nenaudotus granatsvaidžius, po 4 minosvaidžius ir 10 tankų, lengvųjų kulkosvaidžių

93 Kariuomenès štabo I skyriaus referavimas „Mūsų kavalerijos reikalu“, 1940 m. gegužès 24 d. LCVA, f. 929, ap. 3, b. 1134, 1. 36-36 apv. 1.

94 Kariuomenès štabo I skyriaus referavimas „Dèl naujų kavalerijos etatų projekto“, $1940 \mathrm{~m}$. kovo 9 d. LCVA, f. 929, ap. 3, b. 1134, 1. 20.

95 Michelevičius, B. Kavalerija dabartiniuose karuose. Mūsų žinynas, 1940, t. XXXVIII, Nr. 2, p. 257-259.

96 Kariuomenès štabo I skyriaus referavimas „Dèl projektuojamos DLR organizacijos“ [1940 m.]. LCVA, f. 929, ap. 3, b. 1134, 1. 32. 
turejo daugèti nuo 32 iki 42, sunkiụjų - nuo 12 iki 16 , prieštankinių ir priešlèktuvinių pabūklų - patrigubèti - nuo 4 iki 12 . Ateityje KP planuota skirti 21-25 sunkvežimius, 29 motociklus, apie 200 dviračių ir 2-3 motorizuotąsias virtuves ${ }^{97}$. Žinoma, visa tai buvo tik vizijos ir planai. Deja, jie nebuvo igyvendinti, neturint pakankamai tankų, tad karo atveju štabas KP planavo jų skirti ne po 10 , o po $5^{98}$.

\section{Ar tarpukariu buvo reikalinga kavalerija: užsienio patirtis}

Kavaleriją buvo gana brangu išlaikyti. Štai vieno žirgo, Lietuvos kariuomeneje laikomo 10-12 m., šèrimas kainavo dvigubai daugiau negu kareivio maitinimas ${ }^{99} .1939$ m. Kariuomenès štabas suskaičiavo, kad žirgo išlaikymas per mėnesị kainuoja $60 \mathrm{Lt}$, o būtinosios karo tarnybos kario apie $82-85 \mathrm{Lt}^{100}$.

Ivairių svarstymų būta ir tarpukariu ${ }^{101}$, tačiau ieškant atsakymo ị klausimą, ar reikalinga kavalerija, pirmiausia reikètų pažvelgti ị kitų valstybių kariuomenių sudètị, kiek ir kokios kavalerijos dalinių juose buvo. Karyboje, bent jau XX a., paprastai taikos metu kariuomenès stebėdavo, kokie pokyčiai vyksta kaimyninių ir regioninių šalių pajègose, ir iš to darydavo išvadas, ką reikia keisti savosiose. Todèl šiame straipsnio skyriuje nebus nuodugniai tiriama užsienio valstybių kavalerija, siekiant nustatyti jos

\footnotetext{
97 Tamošiūnas, M. Lietuvos kariuomenès kavalerija 1919-1940 m.: tradicijos, kasdienybe, vizijos [baigiamasis bakalauro darbas, Kaunas, 2013]. Žr.: http://www.antraspasaulinis. net/e107_plugins/content/content.php?content.1244

98 Kariuomenès štabo I skyriaus referavimas „Dèl naujų kavalerijos etatų projekto“, 1940 m. kovo 9 d. LCVA, f. 929, ap. 3, b. 1134, apv. 1. 20.

99 Mažeika. Kariuomenès arklių šèrimo išlaidos. Mūsų žinynas, 1937, t. XXXII, Nr. 2, p. 202.

${ }^{100}$ KAM etatams vykdyti įstatymo pakeitimo reikalu, 1939 m. sausio 5 d. LCVA, f. 929, ap. 5, b. $430,1.170$.

${ }^{101}$ Michelevičius, B. Kavalerija dabartiniuose karuose. Mūsų žinynas, 1940, t. XXXVIII, Nr. 2, p. 248-259.
} 
faktinę sudètị ir organizaciją tarpukariu, tik aptariama tai, kas apie ją buvo žinoma ir rašoma to meto Lietuvoje, lyginant su istoriografijos duomenimis. Karo atveju vienos ar kitos kariuomenès rūšies, organizacinès struktūros tinkamumas „patikrinamas" karinių operacijų metu.

$\mathrm{XX}$ a. 4-ojo dešimtmečio pabaigoje Jugoslavijos kariuomeneje taikos metu buvo 17 PD, jas sudare 50 skirtingo dydžio PP, arba apie 160 batalionų ${ }^{102}$. Be to, ji turejo 220 artilerijos baterijų (kuopų), sujungtų i pulkus arba atskirus divizionus, kavaleriją sudarẻ 10 pulkų (2 iš jų - gvardijos), kiekvieną jų - 3 kardų ir 1 kulkosvaidžių eskadronai, taigi iš viso 40 eskadronų. Kavalerijos pagrindu buvo suformuotos 2 divizijos, kiekvieną jų sudarè 2 brigados (2 KP, dviratininku batalionas ir raitosios artilerijos divizionas). Karo atveju, mobilizavus pajègas, pagrindinị operatyvinị vienetą turèjo sudaryti péstininkų arba kalnų divizija, sudaryta iš 3-4 PP, 1-2 AP, 1-2 raitelių eskadronų, pionierių bataliono, chemijos, ryšių ir sanitarijos kuopų, divizijos užnugario tarnybos. KD karo atveju turejo būti sudaryta iš 2 arba 3 brigadų su artilerijos, dviratininkų ir pionierių daliniais. O specialioms užduotims karo metu vykdyti turejjo būti kuriamos mišrios rinktinès ${ }^{103}$.

Bulgarijos kariuomenès 4 korpusuose buvo: 20 PD, 1 lengvoji divizija, 1 kalnų, 3 kavalerijos brigados ${ }^{104}, 3 \mathrm{~KB}$, kiekvienoje iš jų - po $3 \mathrm{KP}$ ir artilerijos dalini $\mathfrak{i}^{105}$. Reorganizuotoje Bulgarijos kariuomeneje $1938 \mathrm{~m}$. buvo 4 korpusai, kuriuos sudarè: 10 PD, 1 greitoji divizija, 1 kalnų, 3 kavalerijos brigados ir kt. daliniai. Iš viso taikos meto pajègas sudare 108 batalionai, 30 kavalerijos eskadronų ir 102 lauko artilerijos baterijos ${ }^{106}$.

Tarpukariu Rumunijos kavalerijos pulkai buvo skirstomi $\mathfrak{i}$ teritorinius (Cãlãrasi) ir reguliariuosius (Rosiori). Taikos metu jos kavaleriją sudarė 12 raudonųjų (Rosiori) ir 8 juodųjų (Cãlãrasi) husarų pulkų, karališkojo es-

\footnotetext{
${ }^{102}$ K. J. Jugoslavija ir jos kariuomenè. Mūsų žinynas, 1939, t. XXXVII, Nr. 9, p. 292.

${ }^{103}$ K. J. Joguslavija: kariuomenè. Mūsu žinynas, 1939, t. XXXVII, Nr. 8, p. 145-146; Mingèla, V. Jugoslavijos kariuomenè. Mūsu žinynas, 1940, t. XXXVIII, Nr. 2, p. 318-320; Молло, Э. Вооруженные силь Второй мировой: структура, униформа, знаки различия. Москва, 2005, с. 111.

104 Bulgarija: artilerija. Mūsų žinynas, 1938, t. XXXIV, Nr. 3, p. 494.

105 Svetimos kariuomenès: Bulgarija. Kardas, 1939, sausio 15, Nr. 2 (304), p. 62.

${ }^{106}$ Bulgarija: kariuomenè. Mūsų žinynas, 1938, XXXV, Nr. 10, p. 619.
} 
korto kavalerijos pulkas, 8 transporto eskadronai. Kavalerija buvo sujungta 3 divizijas ir 1 brigadą ${ }^{107} .1938 \mathrm{~m}$. taikos meto Rumunijos kariuomenè buvo reformuojama, po pertvarkymo ją turejo sudaryti 24 péstininkų ir 4 kavalerijos divizijos, sujungtos i 8 armijos korpusus ${ }^{108}$. Remiantis istoriografija, 1940 m. Rumunija turèjo 9 kavalerijos brigadas ${ }^{109} .1941 \mathrm{~m}$. karą su SSRS Rumunijos kariuomenè pradejo turèdama 6 kavalerijos brigadas, kurias sudare 12 Rosiori ir 6 Cãlãrasi pulkai, be to, dar 7 Cãlãrasi pulkai buvo kitų junginių sudètyje žvalgybos užduotims vykdyti ${ }^{110}$.

1925 m. reorganizuojant Švedijos kariuomenę kavalerijos kiekis buvo labai sumažintas, iš 50 eskadronų liko 17, be to, palikus $4 \mathrm{KP}$, atsisakyta stambių kavalerijos junginių: jie buvo priskirti prie pėstininkų divizijų, o 1 eskadronas paskirtas ị Bodeno tvirtovès (šiaurès Švedijoje, netoli Suomijos) igulą. Kiekvieną pulką sudarè: štabas, ryšių ir šarvuočių būriai, 3 kardų, sunkiųjų kulkosvaidžių ir dviratininkų eskadronai ${ }^{111}$. XX a. 4-ojo dešimtmečio pabaigoje, Tautų Sąjungos duomenimis, Švedijos kariuomenejje tebebuvo $4 \mathrm{KP}$, paskirstyti po atskiras pėstininkų divizijas, taip pat $26 \mathrm{PP}$ po 2 batalionus (iš viso 52 batalionai), $8 \mathrm{AP}$ ir t. t. ${ }^{112}$ Tačiau dešimtmečio pabaigoje greta 6 divizijų Švedijoje buvo nuspręsta suformuoti kavalerijos brigadą, kurios sudètyje būtų ir motorizuotasis batalionas ${ }^{113}$. Po reformų kavalerijos brigadoje turejo būti: štabas, $2 \mathrm{KP}$, artilerijos grupè, atskira kavalerijos rinktinè, ryšių ir pionierių kuopos, gurguolè. Artilerijos grupę turejo sudaryti: 3 baterijos po 4 pabūklus, KP po 3 raitelių, motociklininkų ir sunkiosios ginkluotès (lauko artilerijos būrys, priešlèktuvinès apsaugos būrys ir sunkieji kulkosvaidžiai) eskadronai ${ }^{114}$. Taigi 1936 m. Švedijoje buvo susirūpinta kavalerijos modernizavimu, apie tai galvota ir ją aprūpinant

\footnotetext{
${ }^{107}$ Kriaunaitis. Kitų valstybių kavalerija. Mūsų žinynas, 1928, t. XIV, Nr. 40, p. 58-64.

${ }^{108}$ Kms. Rumunija. Mūsų žinynas, 1938, t. XXXIII, Nr. 4, p. 657.

${ }^{109}$ Молло, Э. Вооруженнье силь Второй мировой: структура, униформа, знаки различия. Москва, 2005, с. 36, 205.

${ }^{110}$ Romanian Cavalry Division. Flames Of War, 1 August 2014, pp. 2-3.

111 Švedija reorganizuoja kavaleriją. Mūsų žinynas, 1936, t. XXXI, Nr. 138, p. 217-272.

${ }^{112}$ Mingèla, V. Švedijos kariuomenè. Mūsu žinynas, 1940, t. XXXVIII, Nr. 5-6, p. 895.

113 Švedija: kariuomenès performavimas. Mūsų žinynas, 1936, t. XXX, Nr. 135, p. 612; Švedija reorganizuoja kavaleriją. Mūsu žinynas, 1936, t. XXXI, Nr. 138, p. 217-272.

${ }^{114}$ V. N. Švedų artilerijos perorganizavimas ir naujos formacijos kariuomenèje. Mūsų žinynas, 1936, t. XXX, Nr. 134, p. 515.
} 
technikos priemonėmis. Buvo nuspręsta suformuoti lengvąją brigadą, kurią sudarytų: štabas, 2 pulkai po 3 raitelių, sunkiosios ginkluotès (sunkiųjų kulkosvaidžių, minosvaidžių, prieštankinis ir motorizuotasis priešlèktuvinès apsaugos būriai), dviratininkų, šarvuočių (12 mašinų) eskadronus. Be to, brigadoje buvo: motorizuotasis kavalerijos divizionas (2 eskadronai), artilerijos grupe (3 baterijos), ryšių ir inžinierių kuopos, motorizuota gurguole ir brigados tarnybos. Brigadą sudare 5000 karių, jai priklausė: 2500 žirgų, 300 automobilių, 200 vežimų, 80 motociklų, 800 dviračių, 12 šarvuočių, 100 sunkiųjų kulkosvaidžių, 12 lauko artilerijos patrankų, 10-12 $37 \mathrm{~mm}$ pabūklų, 20 minosvaidžių. Kiti $2 \mathrm{KP}$ buvo reorganizuoti i 7 motorizuotuosius kavalerijos batalionus, 6 iš jų buvo paskirti i 6 divizijas, o 1 - i lengvają brigadą ${ }^{115}$. Pažymètina, kad Švedijos kariuomenè, prasidejus Antrajam pasauliniam karui, perèjo prie motorizuotųjų kavalerijos dalinių, dalị jų aprūpino tankais. Tai, žinoma, buvo įmanoma dèl Švedijos pramonès galimybių, 1939-1945 m. jos kariuomenè gavo 766 šarvuočius, tanketes ir tankus (48 - CDK m/37, 16 - Landsverk m/38, 20 - Landsverk m/39, 180 - Landsverk m/40, 220 - CDK m/41, 282 - Landsverk m/42) ${ }^{116}$.

Belgijoje tarpukariu iki 4-ojo dešimtmečio vidurio kavalerijos korpusą sudarè $6 \mathrm{KP}, 2$ dviratininkų-motociklininkų pulkai ir artilerijos pulkas. Iš viso buvo 30 kardų ir 12 sunkiųjų kulkosvaidžių eskadronų, šarvuočių rinktiné, artilerijos pulke - 9 raitosios artilerijos ir 2 motorizuotosios baterijos, dvi $75 \mathrm{~mm}$ artilerijos grupès, kurios naudojosi žirgų trauka, viena $75 \mathrm{~mm}$ motorizuotoji ir viena $105 \mathrm{~mm}$ haubicų motorizuotoji grupès. Kiekvienoje KD buvo po 3 kavalerijos pulkus ir 1 dviratininkų pulką. KP sudare 4 kardų, 2 kulkosvaidžių, mokomasis ir atsargos eskadronai. Reformavus kavaleriją, pulkai struktūriškai buvo padalyti ị 2 divizionus ir aprūpinti motorizuotosiomis transporto priemonemis. Kiekvienas pulkas turèjo motociklininkų eskadroną, $47 \mathrm{~mm}$ prieštankinių pabūklų bateriją ir tankų kuopą. Reformuotą korpusą sudarè 2 KD, 2 motorizuotieji pulkai,

\footnotetext{
115 Švedija reorganizuoja kavaleriją. Mūsų žinynas, 1936, t. XXXI, Nr. 138, p. 271-272; Švedija: lengvoji brigada. Mūsų žinynas, 1937, t. XXXII, Nr. 2, p. 236-237; Švedija: kariuomenès performavimas. Mūsuz žinynas, 1936, t. Nr. 135, p. 612.

${ }^{116}$ An Introduction to The Royal Swedish Army in WWII. [žr. 201409 10]. http://wwwsolar.mcs.st-and.ac.uk/ aaron/sweeds.html; Spang, O. Swedish Army Regiment 1939-45 Part II v. 1.0. May 31, 2006 [žr. 201009 10] http://orbat.com/site/history/volume4/443/ SVERIGESREG1939-45[2].pdf
} 
mechanizuotasis artilerijos pulkas (4 grupès), ryšių, inžinierių ir kulkosvaidžių eskadronai. Korpuse liko tik 2 senosios struktūros kavalerijos pulkai, mišriuose KP buvo po 1 kulkosvaidžių ir 2 kardų eskadronus, o motorizuotosiose grupese - po motociklininkų ir tankų eskadroną. Kavalerijos korpusas taikos metu buvo aprūpintas: 336 lengvaisiais ir 256 sunkiaisiais kulkosvaidžiais, 32 13,2 mm kulkosvaidžiais, 48 prieštankiniais $47 \mathrm{~mm}$ pabūklais, 72 lauko artilerijos $75 \mathrm{~mm}$ patrankomis, 24 lengvosiomis $105 \mathrm{~mm}$ haubicomis ir 48 tankais. Toks korpusas savo ginkluotès ugnies galia prilygo 2 belgų péstininkų divizijoms (kiekviena PD turèjo po 102 sunkiuosius kulkosvaidžius, 18 prieštankinių pabūklų ir 36 lauko artilerijos pabūklus), todèl lietuviškoje karinejje periodikoje buvo konstatuojama, kad „naujos santvarkos korpas labiau yra motorizuotas korpas, o ne kavalerijos ${ }^{\text {"117 }}$. Kavalerijos korpuso užduotis karo atveju buvo sienos priedanga. Korpusas, ešelonuodamas gynybą, plačiuose baruose turejo išdèstyti kavalerijos padalinius, o pagrindinių komunikacijos linijų ir priešo veržimosi kryptimis - sutelkti judrius rezervus - tankus, motociklininkų kuopas, motorizuotuosius pulkus ${ }^{118}$. Vis dèlto $1937-1938 \mathrm{~m}$. abi kavalerijos divizijos buvo visiškai motorizuotos ${ }^{119} .1940 \mathrm{~m}$. Belgija buvo mobilizavusi 18 pèstininkų, 2 kalnų jègerių ir 2 kavalerijos divizijas ${ }^{120}$.

Tarpukariu ilgą laiką SSRS buvo laikoma kariniu sąjungininku' ${ }^{121}$, jos karinė galia aukštai vertinta. 1936 m. balandžio 30 - gegužès 5 d. Lietuvos kariuomenès štabo viršininkas gen. št. plk. Jonas Černius ir plk. ltn. Kostas Dulksnys lankèsi Maskvoje. Čia jie, iškilmingai priimti ${ }^{122}$, kartu su Latvijos ir Estijos kariuomenių štabų viršininkais dalyvavo Gegužès 1-osios iškilmèse Raudonojoje aikštejje ${ }^{123}$, susipažino su ginkluotosiomis pajėgomis,

\footnotetext{
117 Sn. Belgija: belgų kavalerijos reorganizacija. Mūsuz žinynas, 1936, t. XXXI, Nr. 141, p. 561. ${ }^{118}$ V. N. Belgija: kavalerijos reorganizacija. Mūsų žinynas, 1936, t. XXX, Nr. 135, p. 610. ${ }^{119}$ Epstein, J. Belgium's Dilemma: The Formation of the Belgian Defense Policy, 1932-1940. New York, 2014, p. 100.

${ }^{120}$ История западноевропейских армий. Ред. В. А. Золотарев. Москва, 2003, с. 427.

${ }^{121}$ Plačiau žr.: Vareikis, V.; Jokubauskas, V. Su kuo Lietuva rengèsi kariauti tarpukariu? Kultūros barai, 2010, Nr. 11 (551), p. 77-84.

${ }^{122}$ Pulk. Černius ir pulk. Dulksnys jau Maskvoje. Lietuvos aidas. 1936, gegužès 1, Nr. 199 (2815), p. 1.

${ }^{123}$ Baltijos valstybių štabų viršininkai Maskvos igulos parade. Lietuvos aidas. 1936, gegužès 2, Nr. 201 (2817), p. 1.
} 
susitiko su aukštaisiais vadais ${ }^{124}$. Po vizito gen. št. plk. J. Černius Raudonąą armiją viešai įvertino labai palankiai: „Raudonoji armija yra galinga, gerai disciplinuota ir aprūpinta moderniškais ginklais. Ypatingo ịspūdžio daro tankai, kurių didesnioji dalis gali nepaprastai greitai žygiuoti<...>. Kavalerija, artilerija ir kitos kariuomenès dalys parade pradefiliavo labai gražiai ir parodė maksimumą to, ko galima iš tų kariuomenès dalių tikètis. " ${ }^{125}$

1938 m. Mūsų žinyne rašoma, kad SSRS RA turejjo 34-36 kavalerijos divizijas, 23 iš jų - europinejje dalyje, 10-12 - Tolimuosiuose Rytuose. Teigiama, kad 18 iš jų buvo kadrinès kavalerijos divizijos, 7 - kadrinès kalnų kavalerijos divizijos, 2 - kadrinès kazokų divizijos, 3 - teritorinès kazokų divizijos. Du trečdaliai sovietų kavalerijos buvo sutelkta europinèje dalyje. Kiekvieną KP sudarè 5 kardų eskadronai po 4 būrius ir sunkiụjų kulkosvaidžių eskadronas, be to, kiekvienas pulkas turëjo raitosios artilerijos 76,2 mm pabūklų bateriją, prieštankinị būrị, žvalgų, sanitarijos ir veterinarijos padalinius. $2 \mathrm{KP}$ sudare kavalerijos brigadą, o 2 brigados - raitosios artilerijos pulkas (6 baterijos, dalis jų ginkluotos haubicomis) - diviziją. Kalnų kavalerijos divizijose buvo po 3 pulkus. Be to, kiekviena KD turejjo chemijos ir pionierių eskadroną, 2 žvalgų eskadronus ir šarvuočių dalini (54 ịvairių modelių šarvuočius) ${ }^{126}$. Sovietai planavo ir modeliavo kavalerijos ir tankų sąveikos galimybes kautynių metu ${ }^{127}$. Faktiškai 1934-1935 m. Raudonosios armijos sudetyje buvo 22 KD (1934 m. - 17 kadrinių ir 5 kalnų, 1935 m. 14 kadrinių, 5 kalnų, 3 teritorinès), 1937 m. - 32 KD (24 kadrinès, 5 kalnų, 3 teritorinès) ir $1 \mathrm{~KB}, 1938 \mathrm{~m}$. - $25 \mathrm{KD}$ (18 kadrinių, 5 kalnų, 2 kazokų) ir 2 KB. 1939 m. spalio 23 d. patvirtintos sudèties pajégose turejo būti: 5 kavalerijos korpusai, 25 divizijos, 1 brigada ir 6 rezerviniai kavalerijos pulkai, iš viso 149 tūkst. karių (pagal patvirtintus etatus RA turèjo būti 2,265 mln. karių, taigi kavalerijoje planuota sutelkti apie 6,6 \% visų karių). 1940 m. vasario $1 \mathrm{~d}$. faktiškai buvo 5 kavalerijos korpusai, 24 divizijos, 2 brigados ir

\footnotetext{
${ }^{124}$ Baltijos štabų viršininkai susipažista su Sovietų kariuomene. Lietuvos aidas. 1936, gegužès 4, Nr. 204 (2820), p. 3; Baltijos štabų viršininkų atsilankymai. Lietuvos aidas. 1936, gegužès 5, Nr. 206 (2822), p. 1.

${ }^{125}$ Pulk. Černius apie Sovietų kariuomenę. Lietuvos aidas. 1936, gegužès 6, Nr. 207 (2823), p. 1.

${ }^{126}$ K. J. SSSR: raudonoji kavalerija. Mūsų žinynas, 1938, t. XXXIV, Nr. 3, p. 497.

127 SSSR: kavalerijos ir tankų bendradarbiavimas ginantis. Mūsų žinynas, 1935, t. XXVIII, Nr. 118, p. 85.
} 
6 rezerviniai kavalerijos pulkai, iš viso 145 tūkst. karių ${ }^{128}$. Nors galima pastebèti ir RA kavalerijos mažèjimo tendenciją, nes pagal 1938-1939 m. RA mobilizacijos planą karo atveju kavalerija turejjo sudaryti 3,8 \% (258 tūkst. iš 6,827 mln., arba 5 kavalerijos korpusus su $29 \mathrm{KD}$ ), pagal $1941 \mathrm{~m}$. mobilizacijos planą karo atveju numatyta kavalerijos dalis RA sumažèjo iki 1,35 \% (117 tūkst. iš 8,683 mln. karių, 3 kavalerijos korpusų su $14 \mathrm{KD})^{129}$.

Po Pirmojo pasaulinio karo nuginkluotos Vokietijos reichsvere galejo tarnauti 100000 žmonių, iš jų 4500 - karininkų. Vokietija negalèjo turèti tankų, buvo ribojama kita ginkluotè. Reichsverą sudarè 7 pėstininkų ir 3 kavalerijos divizijos, ginkluotę - 288 pabūklai, 252 minosvaidžiai ${ }^{130}$. XX a. 4-ojo dešimtmečio viduryje Vokietijos kariuomenèje iš buvusių $3 \mathrm{KD}$ dvi buvo išformuotos, KP išskirstyti ị korpusus ${ }^{131} .1939 \mathrm{~m}$. buvo 1 kavalerijos junginys - I kavalerijos brigada, 1940 m. performuota i I KD, o $1941 \mathrm{~m}$. - i XXIV tankų diviziją. Antrojo pasaulinio karo metu, $1945 \mathrm{~m}$. kovą, Vokietijos kariuomeneje buvo suformuotos dvi - III ir IV - KD, 1943-1944 m. veikè I kazokų divizija, o 1944-1945 m. - visas SS XV kazokų korpusas, sudarytas iš I ir II kazokų divizijų. Nuo $1942 \mathrm{~m}$. veike SS kavalerijos brigada, ji 1943 m. buvo performuota $\mathfrak{i}$ VIII kavalerijos diviziją, taip pat buvo suformuotos XVII ir XXXVII SS savanorių kavalerijos divizijos ${ }^{132}$. Danijos kariuomenès abiejose (Zelandijos ir Jutlandijos) divizijose buvo po vieną

\footnotetext{
${ }^{128}$ Мельтюхов, М. Упущенный шанс Сталина. Схватка за Европу 1939-1941 г2. Москва, 2008, с. 275, 470, 474.

129 Захаров, М. В. Генеральный штаб в предвоенные годы. Москва, 2005, с. 453.

${ }^{130}$ Reichsvero PD sudarè 410 karininkų ir 10830 karių, KD - 201 karininkas ir 5437 kariai: Centek, J. The Military potential of the Reichswehr in East Prussia in January 1923. In Baltijos regiono istorija ir kultūra: Lietuva ir Lenkija. Karinè istorija, archeologija, etnologija. (Acta historica Universitatis Klaipedensis, t. XV). Sud. R. Šliužinskas. Klaipèda, 2007, p. 58. 1929 m. Trimite S. Raštikis rašè, kad Reichsvere tuo metu tarnavo 3798 karininkai, 20880 puskarininkių, 74020 kareivių, 202 karo valdininkai ir 1100 tarnautojų, iš viso 100000 žmonių. Be to, buvo leista turèti 293 karo gydytojus, 200 veterinarų, 7 karo farmacininkus. Vokietijos karines pajègas sudarè: 84 batalionai, 97 eskadronai, 24 artilerijos divizionai, 7 inžinierių batalionai, 7 ryšių ir 7 automobilių rinktinès: Raštikis, S. Vokiečių ginkluotos jègos. Trimitas, 1929, rugsèjo 19, Nr. 38, p. 635-636.

${ }^{131}$ Vokiečių kariuomenès stambieji junginiai. Mūsų žinynas, 1936, t. XXXI, Nr. 139, p. 358.

132 Papečkys, E. Neatsakyti ir diskutuotini tarpukario Lietuvos kariuomenès (1938-1940) istoriografijos klausimai. Karo archyvas, 2010, t. XX, p. 378.
} 
kavalerijos pulką ${ }^{133}, 1937 \mathrm{~m}$. jie buvo reformuoti ir pavadinti žvalgybos pulkais, kiekvieną KP sudarè 2 raitelių, šarvuočių ir šarvuotų sunkvežimių eskadronai ${ }^{134}$. Portugalijos kariuomenèje buvo 60 batalionų ir 36 kavalerijos eskadronai ${ }^{135}$. Vengrijoje tarpukariu 42 batalionams teko 24 kavalerijos eskadronai ${ }^{136}$. Apie $1938 \mathrm{~m}$. Graikijos kariuomenès 4 korpusuose buvo 13 $\mathrm{PD}$ ir $2 \mathrm{~KB}^{137}$, o $1941 \mathrm{~m}$. kariuomenejje - $1 \mathrm{KD}^{138}$.

Taikos metu Estijos kariuomenę sudarė 3 PD, kurių sudètyje buvo 2 PP (1-asis ir 7-asis), 12 atskirųjų pėstininkų batalionų ir atskirasis Talino igulos batalionas. Vieninteli kavalerijos pulką sudarè: štabas, 3 kardų eskadronai, sunkiųjų kulkosvaidžių, technikos ir dviratininkų-slidininkų eskadronai. Pulke tarnavo apie 700 karių. Be to, prie karo mokyklos buvo atskiras eskadronas, o visoje šalyje keletas Kaitseliit eskadronų ${ }^{139}$. Kavalerijos dalis kurti, tobulinant organizacijos struktūrą, pradèta 1925 m. Daugiausia kavaleristų buvo pietineje Estijoje. Kaitseliit kavalerijos dalis $1932 \mathrm{~m}$. buvo planuojama naudoti, ịtraukiant jų personalą, formuojant atskiruosius kavalerijos eskadronus. Tačiau vèlesniais metais Kaitseliit kavalerijos funkcijų padaugejo. $1934 \mathrm{~m}$. rudenị prasidejo kavalerijos dalių reorganizacija, iš jų formuojant teritorinius kavalerijos eskadronus arba būrius, kurie veiktų karo metu. Taip, išnaudojant Kaitseliit potencialą, buvo sprendžiamas kavalerijos dalių aprūpinimo tinkamai parengtais žirgais klausimas. II divizijos apygardoje buvo sudaryti 2 teritoriniai eskadronai ir 12 būrių. $1934 \mathrm{~m}$. kavalerijoje buvo 11 eskadronų ir 7 atskirieji kavalerijos būriai, be to, daug kavalerijos komandų ir skyrių šaulių kuopų sudetyje. Pagal gausumą kavalerija buvo antroji Kaitseliit rūšis, $1934 \mathrm{~m}$. jai priklausė 7,8 \% visų „kaitselitų“ - apie 2,5 tūkst. (iš viso jų buvo 31 569). 1935 m. kariuomenè Kaitseliit perdavé 550 žirgų balnų. Tartu miesto ir Tartu apskrities dalims mokymo

\footnotetext{
${ }^{133}$ Молло, Э. Вооруженнье силь Второй мировой: структура, униформа, знаки разтичия. Москва, 2005, с. 36, 205.

${ }^{134}$ Danija: kariuomenės pertvarkymai. Mūsǔ žinynas, 1937, t. XXXIII, Nr. 9, p. 365.

135 Svetimos kariuomenès: Portugalija. Kardas, 1937, Nr. 2 (256), p. 54.

136 Skirius, J. Istoriniai asmenys ir jų epocha (1918-1945). Kaunas, 1997, p. 187.

137 Graikija: artilerija. Mūsų žinynas, 1938, t. XXXIV, Nr. 5, p. 818.

138 Молло, Э. Вооруженные силь Второй мировой: структура, униборма, знаки разтичия. Москва, 2005, с. 36, 205.

${ }^{139}$ Estijos kariuomenè, 1938 m. liepos 1 d. LCVA, f. 929, ap. 2, b, 1062, 1. 10-17, 36.
} 
procese talkino ten stovejęs vienintelis Estijos kariuomenès kavalerijos pulkas. 1935 m. visi Jervos apskrities kavalerijos eskadronai ir būriai, pasirengę mokymams, buvo unifikuoti ir sudarè kavalerijos rinktinėlę (est. ratsamalevkond), kuri vèliau buvo pavadinta kavalerijos divizionu. $1938 \mathrm{~m}$. Tartu apskrities būriams buvo paskirtas bendras vadas ${ }^{140}$.

Kaitseliit eskadroną turejjo sudaryti 3-4 kovos būriai ir 1 bendras būrys, tačiau galejjo egzistuoti ir eskadronai, sudaryti iš 2 kovos būrių. Minimalus eskadrono dydis - 80 vyrų. Mobilizacijos atveju $1938 \mathrm{~m}$. planuota iš šių teritorinių dalių suformuoti 6 atskiruosius žvalgybos eskadronus, pėstininkų pulkų kavalerijos būrius ir papildyti kavalerijos pulko padalinius. Atskirieji eskadronai buvo priskirti prie brigadų ir turèjo atlikti žvalgybą. Juos sudarè: štabas, bendrasis būrys, 2 kavalerijos būriai ir slidininkų-dviratininkų būrys, iš viso 195 vyrai ir 151 žirgas. Kiekvienam eskadronui apginkluoti turèjo būti skirta po 6 lengvuosius kulkosvaidžius ${ }^{141}$.

Po Nepriklausomybès kovų iki $1921 \mathrm{~m}$. Latvijos kariuomenëje buvo 5 atskirieji kavalerijos eskadronai. Jie, reformuojant karines pajègas, buvo sujungti ị kavalerijos pulką, kurị sudarè: 5 kardų, mokomasis ir sunkiųjų kulkosvaidžių eskadronai, ryšių, technikos, remonto ir ūkio komandos. 1928 m. pulke jau buvo tik 4 kardų eskadronai po 4 būrius ir kulkosvaidžių eskadronas $^{142}$. Latvijos kariuomeneje taikos metu buvo 4 PD (12 PP) ir 1 KP, iš viso 28 batalionai po 4 raitelių, 2 sunkiųjų kulkosvaidžių eskadronus, 24 lengvosios, 6 sunkiosios ir 3 priešlèktuvinès artilerijos baterijos ${ }^{143}$. Be to, kiekviename Aizsargi teritoriniame pulke buvo 1-2 kavalerijos eskadronai ${ }^{144}$.

\footnotetext{
${ }^{140}$ Salo, U. Kaitseliit vaidmuo Estijos gynybos sistemoje 1918-1940 metais. In Paramilitarizmas rytu Baltijos regione 1918-1940: atvejo studijos ir lyginimai (Acta Historica Universitatis Klaipedensis, t. XXVIII). Sud. V. Jokubauskas; V. Safronovas; V. Vareikis. Klaipėda, 2014, p. 197-217.

141 Ten pat.

${ }^{142}$ Kriaunaitis. Kitų valstybių kavalerija. Mūsų žinynas, 1928, t. XIV, Nr. 40, p. 64-68.

${ }^{143}$ V. N. Latvija: kariuomenès organizacija. Mūsų žinynas, 1937, t. XXXII, p. 499-500; Ciganovs, J. «Dievs, Tēvija, pulks» Latvijas armijas Jātnieku pulks. [žr. 2014 09 05]. http:// www.sargs.lv/lv/Vesture/Vesture/2013/03/08-01.aspx\#lastcomment

${ }^{144}$ Pētersons, A. Krustugnis. 60 gadus no tautas slēptais 1940-1945. Rīga, 2007, 1. 114-115, 83-84; Butkus, A. Latviai, Kaunas, 1995, p. 51; Latvijos kariuomenė 1938 m. LCVA, f. 929, ap. 2, b. 1065, 1. 25.
} 
$\mathrm{XX}$ a. 4-ojo dešimtmečio antroje pusejje Suomijos kariuomenèje buvo 3 PD ir KB: iš viso 26 péstininkų (tarp jų 3 - dviratininkų) batalionai, 8 kardų eskadronai, 2 sunkiųjų kulkosvaidžių eskadronai, artileriją sudarẻ 19 lengvụjų, 22 sunkiosios (kartu su pakrančių) ir 3 priešlèktuvinès artilerijos

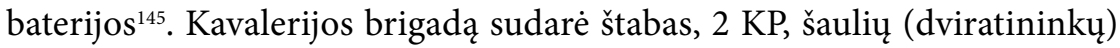
batalionas ir raitoji artilerija ${ }^{146}$. Pulkuose buvo po 4 raitelių ir po 1 sunkiųjų kulkosvaidžių eskadronus ${ }^{147}$. Pagal $1941 \mathrm{~m}$. etatus brigadoje tarnavo 163 karininkai, 486 puskarininkiai ir 3589 kareiviai, iš viso 4238 kariai $^{148}$.

Tarpukariu Lietuvos karineje spaudoje rašyta apie Lenkijos kariuomenę ir jos kavaleriją. Lietuviškoje karineje spaudoje buvo perspausdinamos publikacijos, kuriose svarstoma apie Lenkijos kariuomenès kavalerijos panaudojimo galimybes. Teigta, kad, pasak lenkų autorių, ateities kare kavalerijai teks svarbus vaidmuo, nes karas bus manevrinis, vyks plačiuose frontuose, kur liks atviri sparnai, tarpai tarp kariuomenès junginių. Todèl tikètasi, kad tokiomis sąlygomis kavalerija turès daug galimybių veikti, o lemiamais momentais ir pagrindinèmis kryptimis bus naudojami dideli jos junginiai. Tačiau kartu pažymèta, kad su kitų kariuomenės rūšių pajègomis kavalerija negali kautis raita, vadinasi, turi būti pritaikyta veikti pèsčia, turèti daug ugnies priemonių ${ }^{149}$. Lenkijos kariuomenès karininkų nuomone, ateities kare greita kavalerija turès priešui sukurti netikètumų ir tai išnaudoti, jos daliniai mūšyje vaidins lemiamą vaidmenị. Atsižvelgiant i vietos geografines (upes, miškų, pelkių masyvus) ir kitas (sniego dangą, polaidžių ypatumus) sąlygas, Lenkijos kariuomenei labiausiai buvo priimtina formuoti kavalerijos junginius su šarvuočiais ${ }^{150}$. Taigi, remiantis šiomis Lenkijos autorių mintimis, Lietuvos karinè vadovybė pagrịstai galejjo tikètis karo atveju susidurti su judriais lenkų kavalerijos daliniais, kuriems pavesta netikètai atakuoti, prasiveržti ị užnugarị ir t. t.

${ }^{145}$ V. N. Suomija: kariuomenès organizacija ir skaičius. Mūsų žinynas, 1937, t. XXXII, Nr. 4, p. 501.

${ }^{146}$ Молло, Э. Вооруженнье силь Второй мировой. Структура, униформа, знаки различия. Москва, 2005, p. 27.

${ }^{147}$ Suomija. Mūsų žinynas, 1936, t. XXX, Nr. 135, p. 613.

${ }^{148}$ Jowett, P.; Snodgrass, B. Finland at War 1939-45. Oxford, 2006, p. 20.

${ }^{149}$ Lenkija: kavalerijos motomechanizacija. Mūsų žinynas, 1935, t. XXVIII, Nr. 118, p. $81-83$.

${ }^{150}$ Svetimos kariuomenès: Lenkija. Kardas, 1938, Nr. 21 (299), p. 496. 
Lietuvos karinejje spaudoje teigta, kad XX a. 4-ojo dešimtmečio pabaigoje Lenkijos, vieno iš pagrindinių Lietuvos karinių priešų tarpukariu, kariuomeneje taikos metu buvo 323 péstininkų batalionai, 273 kavalerijos eskadronai ir 481 artilerijos baterija ${ }^{151}$. Lietuvos kariuomenė atidžiai stebejjo kaimynų pajègas, 1936 m. štabo dokumentuose konstatuota, kad Lenkijos kavaleriją sudaro 40 pulkų, iš jų 3 - švoležerų, 10 - raitujų šaulių, 27 - ulonų, ir kad visa kavalerija sujungta ị kavalerijos diviziją ir 12 atskirujų kavalerijos brigadų. Dokumente smulkiai išanalizuota Lenkijos kavalerijos struktūra nuo divizijos iki eskadrono ${ }^{152}$. Žinoma, dèl pateiktų duomenų patikimumo kyla pagrịstų abejonių, nes $37 \mathrm{KP}$ tikrai negalejo sudaryti tiek eskadronų, tačiau tai rodo, kaip Lietuvos kariuomenèje buvo vertinamos Lenkijos pajėgos, ypač kavalerija. $1933 \mathrm{~m}$. analizuojant Lietuvos kariuomenès kavalerijos reformavimo galimybes turimos pajègos lygintos būtent su Lenkijos kavalerija, savo kavaleriją siekta modernizuoti pagal lenkų pavyzdị ${ }^{153}$. Pasibaigus karui, po demobilizacijos $1924 \mathrm{~m}$. Lenkijos kariuomeneje buvo 40 KP. 1937 m. Lenkijos kariuomenejje buvo 11 kavalerijos brigadų: 5 brigados po 4 pulkus ir po 16 lauko artilerijos pabūklų, 6 brigados po 3 pulkus ir po 12 lauko artilerijos pabūklų. Trys kavalerijos brigados (I, XII ir XVII) išformuotos, viena - reorganizuota $i$ motorizuotąją ${ }^{154}$. Tiek pat (40) kavalerijos pulkų išliko iki pat Antrojo pasaulinio karo pradžios, tačiau 3 iš jų buvo motorizuoti ir priklausė dviem motorizuotosioms brigadoms. Dar vieną kavalerijos pulką (kurị sudarẻ 8 eskadronai, o ne 4 etatiniai) ir 12 kavalerijos eskadronų suformavo Pasienio apsaugos korpusas. 1939 m. iš mobilizuotų karių, viršijus numatytą etatinị jų skaičių, buvo suformuoti 3 rezerviniai ulonų pulkai ir sujungti ị rezervinę Volkovysko kavalerijos brigadą.

Taigi XX a. 4-ajame dešimtmetyje, remiantis Lietuvos karine spauda, kuri atspindi ir Lietuvos karininkų žinias bei požiūrị i kavaleriją, taikos metu Jugoslavijos kariuomeneje péstininkų batalionų ir kavalerijos eska-

\footnotetext{
${ }^{151}$ Lenkų kariuomenès sudètis. Mūsų žinynas, 1939, t. XXXVI, Nr. 5, p. 819.

${ }^{152}$ Lenkų kavalerija, 1936 m. LCVA, f. 1326, ap. 1, b. 239, 1. 50-54.

${ }^{153}$ Kavalerijos perorganizavimo projektas, 1933 m. rugsèjo 16 d. LCVA, f. 1326, ap. 1, b. $163,1.207$.

${ }^{154}$ Pawłowski, T. Armia marszałka Śmigłego. Idea rozbudowy Wojska Polskiego 1935-1939. Warszawa, 2009, s. 244, 250.
} 
dronų santykis ${ }^{155^{*}}$ buvo 4 ir 1 (160:40), Švedijos - 3 ir 1 (52:17), Portugalijos $-1,7$ ir 1 (60:36), Bulgarijos - 3,6 ir 1 (108:30), Suomijos $-3,25$ ir 1 (26:8), Latvijos -7 ir 1 (28:4), Estijos - 6,3 ir 1 (19:3), Lenkijos - 1,2 ir $1(323: 273)^{156^{* *}}$ ir t. t. Tuo metu Lietuvos kariuomeneje 21 pėstininku batalionui teko 12 eskadronų ( $3 \mathrm{KP}$ po 4 kardų eskadronus), t. y. santykis buvo 1,75 ir 1 . Svarbu pabrèžti, kad priešai ir tikètinas karo pobūdis, be šalies ūkinių ir komunikacijų infrastruktūros galimybių, buvo vieni svarbiausių veiksnių, lėmusių kavalerijos kieki. Ten, kur planuota ginti konkrečias, kai kada net ịtvirtintas pozicijas, kavalerijos buvo gerokai mažiau, o kur rengtasi manevriniam karui - daugiau.

\section{Teritorinẻ kavalerija: šauliai dragūnai}

Apie teritorinès kavalerijos sudarymą Lietuvoje svarstyta jau XX a. 3-iajame dešimtmetyje. 1928 m. birželio 14 d. krašto apsaugos ministras gen. ltn. Teodoras Daukantas ir Vyriausiojo štabo viršininkas gen. št. plk. Povilas Plechavičius kreipèsi ị Lietuvos Vyriausybę: „[Š]iuo laiku daugiausiai galimas mūsų priešas yra lenkai. Okupuotam Vilniaus krašte jie laiko didelị kariuomenès dalių skaičių. <...> Be kitų ginklų rūšių kariuomenès dalių, lenkai okupuotame krašte laiko 6 kavalerijos pulkus su raitąja artilerija. Tokia kavalerijos masè, kilus ginkluotam konfliktui, galètų mums daug pakenkti, ypač pirmomis karo dienomis, nes ịsiveržusi ị mūsų kraštą trukdytų mobilizaciją, sunaikintų ryšių ir susisiekimo priemones, sukeltų paniką gyventojų tarpe, padarytų mums daug materialinių nuostolių ir t. t. “157

\footnotetext{
155 *Tekste nurodytas pèstininkų batalionų ir kavalerijos eskadronų skaičius Europos valstybių kariuomenèse tarpukariu nèra visiškai tikslus dèl dviejų priežasčių: 1) dauguma duomenų paimti ne iš archyvinių dokumentų, o iš periodinių leidinių; 2) ne visada pavyko nustatyti, ar ten pateiktas bendras kariuomeneje suformuotų (t. y. su kulkosvaidžių, technikos, štabo ir kt. eskadronais), ar tik raitelių, vadinamųjų kardų, eskadronų skaičius. $156{ }^{* *}$ Kaip minèta, pastarasis santykis neatitinka faktinès padèties, nes $37 \mathrm{KP}-148$ kardų eskadronai.

${ }^{157}$ Krašto apsaugos ministerijos 1928 m. birželio 14 d. raštas Ministerių kabinetui. LCVA, f. 929 , ap. 5 , b. $316,1.42$.
} 
Toliau buvo dėstoma, kad tokias gausias Lenkijos kariuomenės kavalerijos pajègas galètų atremti stipri Lietuvos kavalerija.

Tačiau Lietuvos ekonominè padètis neleido taikos metu išlaikyti daugiau kaip 2 KP, o tiek buvo tikrai per mažai, žinant lenkų pajėgų dydį, kad galima būtų ilgai priešintis gausesnei priešo kavalerijai. Tų dviejų pulkų vargu ar būtų pakakę Lietuvos kariuomenès mobilizacijai pridengti. Sąlygos (ilga siena su kaimynine valstybe ir tai, kad Lenkijos pajègos buvo judrios) vertė ieškoti sprendimo. Karo atveju greitai padidinti kavaleriją sunku, ypač neturint tinkamai parengtų karių ir žirgų, o kavalerijos veiksmai, atsižvelgiant $\mathfrak{i}$ Lietuvos kariuomenès operatyvinius sumanymus, turètų išskirtinę svarbą būtent karo pradžioje, t. y. kai reikètų užtikrinti priedangą. Konstatuota, kad, net ir turint pakankamai parengtų kavalerijos atsargos karių (jeigu pavyktų per 3-4 d. juos mobilizuoti), problema nebūtų išspręsta - iš gyventojų rekvizuoti žirgai dar ilgai, kol būtų išmokyti, netiktų kautynèms ${ }^{158}$.

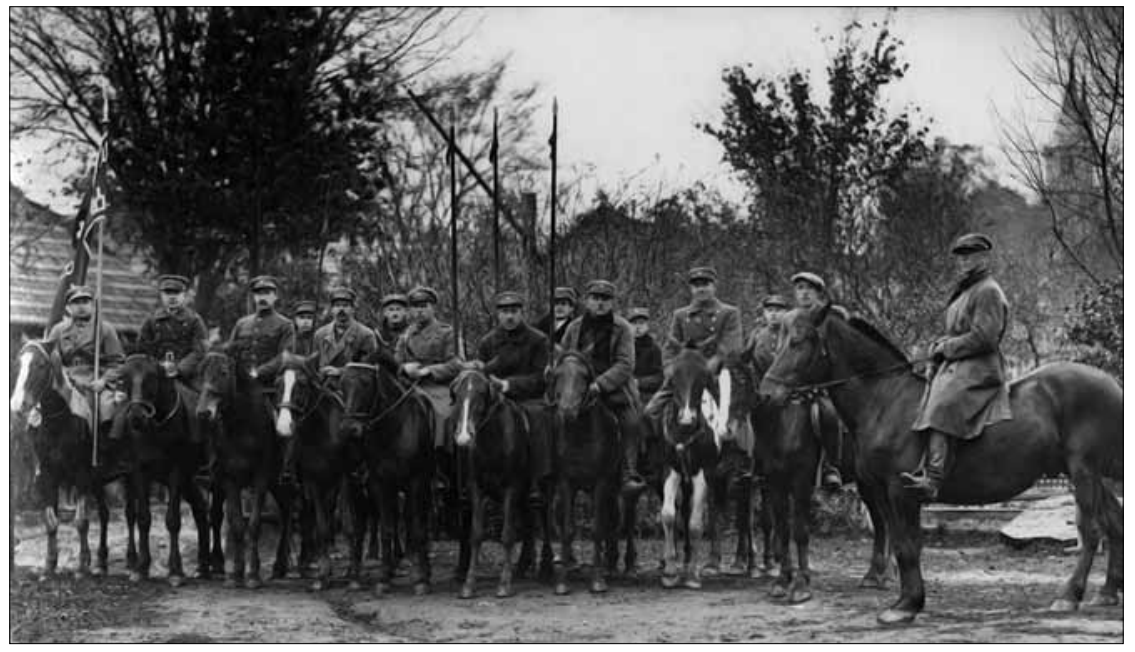

Šaulių dragūnų būrys, 1930 m. dalyvavęs Tverų šaulių pratybose (LCVA)

${ }^{158}$ Krašto apsaugos ministerijos 1928 m. birželio 14 d. raštas Ministerių kabinetui. LCVA, f. 929 , ap. 5 , b. $316,1.42$. 
Kavalerijos žirgui parengti reikejo mažiausiai pusmečio ${ }^{159}$. Todèl karinè vadovybė, vadovaudamasi Karo tarybos sprendimu, pasiūlè kurti teritorinius kavalerijos dalinius ir pavadinti juos Mirties Husarais. Tokiu atveju buvo tikimasi: a) turèti apie 2400 paruoštų atsargos kavaleristų su žirgais (skaičiavimas paremtas teorine prielaida, kad pusė iš 4800 tuo metu buvusių atsargos kavaleristų stos ị dalinị Mirties Husarai); b) gerokai padidinti Lietuvos kavalerijos kovinę vertę, nors teritorinès kavalerijos vertė vis tiek būtų buvusi menkesnè nei reguliariųjų dalinių, tačiau dèl pigumo (vidutiniškai reguliariųjų pajėgų kavalerijos kario su žirgu ir visa ekipuote išlaikymas per metus kainavo apie 2695 Lt, o Mirties Husaro - 159 Lt, t. y. 17 kartų pigiau) galima turèti kur kas daugiau kavaleristų; c) kad teritorinè kavalerijos struktūra labai paspartins pajėgų mobilizaciją; d) kad tokia struktūra padès pagerinti žirgų laikymo krašte kokybę ${ }^{160}$. Parengtame Mirties Husaru statute buvo numatyta į tarnybą priimti atsargos kavaleristus iki $45 \mathrm{~m}$. teritoriniu principu, atsižvelgiant $\mathfrak{i}$ Lietuvos administracini suskirstymą, turejo būti formuojami skyriai, būriai, šimtinès, rinktinès ir pulkai. Planuota, kad skyriaus formavimo teritorijos spindulys nesiektų toliau kaip $20 \mathrm{~km}$ (apskaičiuota, kad Lietuva būtų padalyta ị mažiausiai 40 skyrių teritorijas). Tarnauti būtų galèję stoti vyrai, turintys kavalerijai tinkamą žirgą ir ekonomiškai pajègūs jị išlaikyti, neteisti, tinkantys rikiuotès tarnybai ir gyvenantys ne toliau kaip $20 \mathrm{~km}$ nuo skyriaus rinkimosi vietos. I tarnybą planuota priimti 5 metams, suteikiant galimybę terminą pratęsti, ìstojusiems ị tarnybą kasmet (5 metus) mokèti po 300 Lt žirgui išlaikyti, duoti kavalerijos balną su reikiamais priedais ir kavaleristo kardą. Be to, buvo numatyta mokèti atlyginimus: eiliniam husarui - 18 Lt per metus, skyrininkui - 5 Lt per mènesị, būrininkui -8 Lt per mènesį, karininkui šimtininkui - 50 Lt per mènesị, karininkui rinktinès vadui - 70 Lt per mėnesí, karininkui pulko vadui - 100 Lt per mėnesį. Visi uniformą, kurią galëjo nešioti ir ne tarnybos metu, ịsigyti turèjo savo lèšomis, o mokymuose per metus su žirgu dalyvauti ne mažiau kaip 150 val. ${ }^{161}$

\footnotetext{
159 Širmulys, A. Vyrai, balnokim žirgus! Trimitas, 1935, vasario 21, Nr. 8, p. 136.

${ }^{160}$ Krašto apsaugos ministerijos 1928 m. birželio 14 d. raštas Ministerių kabinetui. LCVA, f. 929 , ap. 5 , b. $316,1.42$.

${ }^{161}$ Laikinasis Mirties Gusary statutas. Projektas, 1928 m. LCVA, f. 929, ap. 5, b. 316, 1. 44-49.
} 
Vis dèlto kol kas turimi duomenys neleidžia teigti, kad aptartas Mirties Husarų teritorinès kavalerijos projektas buvo ịgyvendintas, nors toliau išdèstyti faktai rodo, kad teritorinès kavalerijos sumanymą imtasi igyvendinti pasitelkus Lietuvos šaulių sąjungos struktūrą.

Tarpukariu tikètasi, kad karo pradžioje priešo kavalerija stengsis sutrukdyti vykdyti mobilizaciją, terorizuos gyventojus, naikins ryšių priemones. Sulaikyti priešo kavalerijos įsiveržimą, ją persekioti ir neutralizuoti, dengti savo pajègų mobilizaciją, prasivežti i̇ priešo užnugarị, sparčiai veržtis persekiojant priešininką po pergalès mūšyje, aktyviai veikti savo ir priešo pajègu sparnuose, taip pat priešininko užnugaryje galejjo tik stiprūs kavalerijos daliniai. Todèl buvo būtina jau taikos metu organizuoti kavalerijos dalinius ir rezervą, kad karo atveju juos operatyviai galima būtų mobilizuoti. Šiems tikslams igyvendinti siūlyta plètoti „tautiškais pagrindais organizuojamus tik iš kavalerijos atsargos karių teritorinius raitininkus“. Iš tokių savanorių, aprūpintų karabinais, kardais, pikèmis, balnais, kamanomis, uniformomis, suformuoti kelis kavalerijos pulkus. Preliminariai buvo suskaičiuota, kad per metus toks kavaleristas kainuotų apie 90 Lt, arba 30 kartų pigiau negu reguliariųjų kavalerijos dalinių karys. Taip pat siūlyta tokiems atsargos kavaleristams iki metų sutrumpinti būtinąją karo tarnybą, o šalyje išplètojus raitelių rezervą, kavalerijos dalinius aprūpinti automatiniais ginklais, šarvuočiais ir arterija. Jie turejo būti tiesiogiai pavaldūs kariuomenès, o ne pėstininkų divizijų vadovybei. Aprūpinti naujausia ginkluote, disponuojantys didele ugnies galia kavalerijos daliniai turejo būti judrūs kaip pėstininkai. Divizijose iš raitųjų žvalgų komandų siūlyta formuoti atskirus, kad ir menkesnès ugnies galios, eskadronus ${ }^{162}$.

Teritorinè šaulių dragūnų struktūra buvo sukurta ir gana plačiai veikè. Lietuvos šaulių sąjungos štabe buvo karininkas šaulių dragūnų reikalams ${ }^{163} .1930$ m. rugsèjo 25-29 d. didžiuosiuose kariuomenès manevruose dalyvavo 3 šaulių dragūnų eskadronai ir 1 šaulių péstininkų kuopa ${ }^{164}$. 1931 m. spaudoje dèstyta, kad „numatant, ištikus karui, nieku kitu nepakeičiamų raitininkų pareigų ir sunkumą juos komplektuojant, kilo sumanymas ruošti didesnị skaičių tinkamų karo tarnybai raitininkų, stei-

\footnotetext{
162 Kurklietis, J. Šaulių raitininkų reikšmè. Kardas, 1932, balandis, Nr. 4 (36), p. 50-51.

${ }^{163}$ Sportas. Trimitas, 1938, kovo 31, Nr. 13 (902), p. 328.

164 Iš šaulių gyvenimo. Trimitas, 1930, spalio 2, Nr. 40, p. 829.
} 


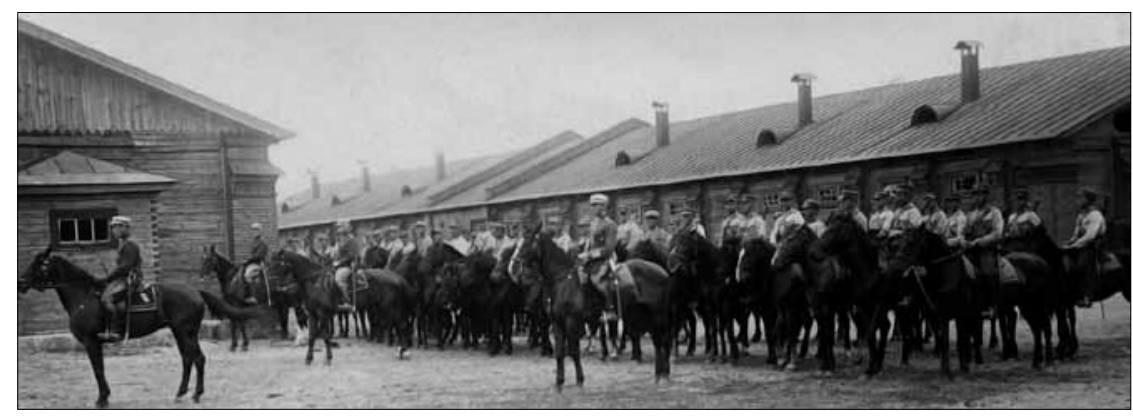

Marijampolès šauliai dragūnai, vadovaujami 2-ojo KP karininkų, išvyksta ị mokymus. XX a. 4-asis dešimtmetis (LCVA)

giant prie šaulių organizacijos vietos teritorinę kavaleriją. Šios kavalerijos vardas visuomeneje ne pirmas kartas yra girdimas ir įvairiai komentuojamas: šauliais-raiteliais, mirties husarais ir kitais vardais. Bet dabar jau yra nusistojęs šaulių dragūnų vardas" ${ }^{\text {165 }} .1931 \mathrm{~m}$. buvo patvirtinta 60 val. šaulių dragūnų mokymo programa ${ }^{166} .1932$ m. Trimite rašoma: „Šiandien yra gražios progos prikelti raitelius iš amžių miego ir suburti juos šaulių dragūnų eilèse, nes raitųjų vyrų kadrų mūs tauta reikalinga. Jie gali turèti didelès reikšmès ateities žygiuose Vilniui ir okupuotosioms Lietuvos žemèms vaduoti. Šaulių dragūnų uždaviniai platūs ir nelengvi. “167 Šauliai dragūnai tarnauti pasižadèdavo 2-6 m. Kavalerijos viršininkas reikalavo, kad dragūnų eskadronai nuolatos būtų pasiruošę mobilizacijai (visos sudèties ir su savo žirgais) ${ }^{168}$.

Apie 1935 m. buvo siūloma prie kiekvieno LŠS būrio ịsteigti 6-8 šaulių raitelių padalinị, pusẻ iš jų būtų mobilizuojami šauliai, tada kiekvienoje rinktinèje taikos metu būtų 223 raiteliai, karo metu - 113, LŠS atitinkamai - 4460 ir 2250 raitụjų šaulių. Taikos metu raitụjų šaulių padaliniuose atsargos kariai, tarnavę kavalerijos daliniuose, atnaujintų žinias, palaikytų jojimo igūdžius, o tarnavę pèstininkais - išmoktų jojimo technikos ir ka-

${ }^{165}$ Kurklietis, J. Šauliai-dragūnai. Trimitas, 1931, gegužès 7, Nr. 19, p. 366.

${ }^{166}$ LŠS šaulių dragūnų pozityvios tarnybos programa, $1931 \mathrm{~m}$. birželio $16 \mathrm{~d}$. LCVA, f. 561, ap. 18, b. 101, 1. 1-5 apv. 1 .

${ }^{167}$ Kurklietis, J. Senovès lietuvių raitininkai. Trimitas, 1932, sausio 1, Nr. 1, p. 8.

${ }^{168}$ LŠS vado 1935 m. kovo 26 d. ịsakymas I, VI ir XIV rinktinių vadams. LCVA, f. 561, ap. 2, b. $859,1.121$. 
valerijos veikimo taktikos. Mobilizacijos atveju turejo būti skiriami ị kavalerijos ir artilerijos dalinius. Buvo svarbu ir tai, kad raitieji šauliai jau taikos metu rengtų savo žirgus veiksmams kariuomenès kavalerijos daliniuose. Šaulius siūlyta aprūpinti balnais ir kamanomis, kurie taptų jų nuosavybe, o nemobilizuojamiems - dar išduoti karabinus ir kardus ${ }^{169} .1939$ m. kovo 31 d. duomenimis, LŠS iš viso priklausė 1417 šaulių raitelių, daugiausiai raitelių buvo I Kauno - 120, III Telšiu - 119, VI Ukmergès - 130, XIV Marijampolès - 128, XVIII Biržų - 100 - rinktinèse ${ }^{170}$. Tais pačiais $1939 \mathrm{~m}$. LŠS 20-mečio šventëje Kaune dalyvavo 294 šauliai raiteliai ${ }^{171}$.

Šaulių uniformų sagos buvo vienodos - kariuomenès pavyzdžio, o ịsiuvų spalva skyrėsi: šaulių pėstininkų - geltona, šaulių raitelių ir dragūnų balta $^{172}$. Atskiruose raitelių daliniuose tarnaujantiems ant kelnių iš abiejų balto įsiuvo pusių turẻjo būti užsiuvami tamsiai žalios spalvos antsiuvai dvi $2,5 \mathrm{~cm}$ pločio juostelès ${ }^{173}$. Taigi skiriamasis šaulių dragūnų uniformos akcentas buvo žali antsiuvai ${ }^{174}$.

Spaudoje agituota: „Šauliai ats. kavaleristai ir kurie tik jaučia savyje noro būti raitininku, visi ị šaulius dragūnus. Atgaivinkime senovès raitiją. " 175 Buvo raginama, prie šaulių būrių leidus steigti šaulių dragūnų skyrius: „Kas turime žirgus, visi stokime ì šaulių dragūnų eiles." ${ }^{176}$ Šios agitacinès citatos paimtos iš 1935 ir 1937 m. Trimito, t. y. kai jau veike teritorinių dragūnų tarnyba.

\footnotetext{
169 Šaulių raitelių [1935 m.]. LCVA, f. 561, ap. 2, b. 859, 1. 179-181.

${ }^{170}$ II Utenos - 19, IV Tauragès - 62, V Trakų - 78, VII Šiaulių - 72, VIII Vilkaviškio - 22, IX Seinų - 90, X Rokiškio - 92, XI Rasienių - 32, XII Panevėžio - 88, XIII Mažeikių - 41, XV Kretingos - 44, XVI Kèdainių - 55, XVII Šakių - 48, XIX Alytaus - 88, XXI Zarasų 9 šauliai raiteliai: Kavalerijos štabo viršininkui, 1939 m. kovo 31 d. LCVA, f. 561, ap. 18, b. $181,1.19$.

${ }^{171}$ LŠS 20-čio šventejje dalyvavusių šaulių žinios, 1939 m. liepos 30 d. LCVA, f. 561, ap. 2, b. $4484,1.1$.

${ }^{172}$ LŠS štabo paliepimai ir pranešimai, 1935 m. gruodžio 17 d. Trimitas, 1935, gruodžio 20, Nr. 51-52 (784-785), p. 964.

${ }^{173}$ Isakymas Šaulių sąjungai Nr. 24, Kaunas, 1935 m. gruodžio 17 d. Trimitas, 1935, gruodžio 20, Nr. 51-52 (784-785), p. 964.

174 Iš šaulių gyvenimo. Trimitas, 1935, kovo 14, Nr. 11, p. 197.

175 Širmulys, A. Vyrai, balnokim žirgus! Trimitas, 1935, vasario 21, Nr. 8, p. 136.

${ }^{176}$ Petrulionis, J. Šauliai dragūnai. Trimitas, 1937, liepos 8, Nr. 27 (864), p. 647.
} 


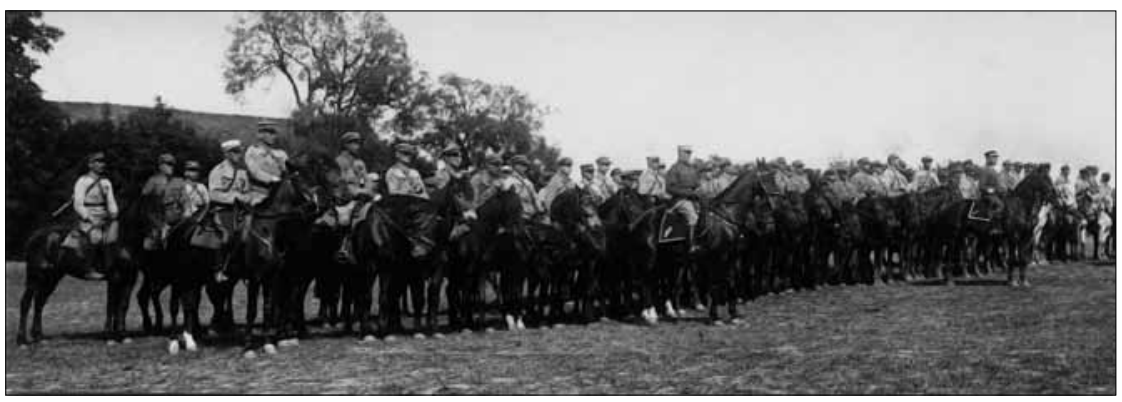

Šaulių dragūnų būrys apie 1934 m. (LCVA)

Šaulių savaitraštyje gausu trumpų žinučių apie šaulių dragūnų būrių steigimą, paradus ir kitą veiklą. $1935 \mathrm{~m}$. Giedraičiuose įsikūrè šaulių dragūnų būrys ${ }^{177}, 1937 \mathrm{~m}$. Kretingalèje - šaulių dragūnų skyrius ${ }^{178} .1938 \mathrm{~m}$. pradžioje Endriejavo šaulių būrys organizavo "raitųjų šaulių dragūnų“ grandị $\mathfrak{i}^{179}$. Ilgakiemyje planuota steigti šaulių dragūnų skyrių ${ }^{180}$ ir t. t. Šauliai dragūnai dalyvaudavo specialiuose šaulių padalinių manevruose ${ }^{181}$, o manevruose kartu su reguliariosios kariuomenès daliniais - teritoriniai dragūnai ir raitieji šauliai ${ }^{182}$. Štai 1937 m. šauliai dragūnai dalyvavo šventiniame parade ant Šatrijos kalno vykusioje Žemaičių dienų šventejje ${ }^{183}$. Apskritai periodineje spaudoje LŠS priklausantys kavaleristai buvo vadinami ịvairiai: „raitieji šauliai dragūnai“, „šauliai dragūnai“, „raitieji šauliai“, „,raiteliai dragūnai“ arba tiesiog „dragūnai“.

\footnotetext{
177 Iš šaulių gyvenimo. Trimitas, 1937, liepos 15, Nr. 28 (865), p. 666.

178 Iš šaulių gyvenimo. Trimitas, 1937, liepos 2, Nr. 26 (863), p. 619.

${ }^{179}$ Iš šaulių gyvenimo. Trimitas, 1938, kovo 3, Nr. 9 (898), p. 229.

${ }^{180}$ Iš šaulių gyvenimo. Trimitas, 1938, gegužès 19, Nr. 20 (909), p. 494.

${ }^{181}$ Kl. M. Šaulių manevrai. Trimitas, 1937, rugsèjo 30, Nr. 39 (876), p. 922.

182 Iš karių gyvenimo. Trimitas, 1937, kovo 11, Nr. 10 (847), p. 237.

${ }^{183}$ Ivairios žinios. Trimitas, 1937, birželio 17, Nr. 24 (861), p. 570.
} 


\section{Teritorinių dragūnų tarnyba}

Teritorinių dragūnų ịstatymas buvo priimtas $1934 \mathrm{~m}$. gegužès $1 \mathrm{~d} \cdot{ }^{184} \mathrm{I}$ šią tarnybą buvo imami vyrai, privalantys atlikti karo prievolę ir tinkami tarnauti kavalerijoje. Visi norintieji prašymus teikdavo apskričių komendantams, o tarnaujantys - pulkų vadams. Pretendentai turejo turèti sąlygas laikyti žirgą. Priimti dragūnai 7 mèn. tarnaudavo reguliariosios kariuomenès kavalerijos pulkuose, paskui buvo paleidžiami $7 \mathrm{~m}$. lygtinių atostogų, tačiau jų metu bet kada galejjo būti pašaukti tęsti tarnybos. Kiekvienas dragūnas gaudavo uniformą, žirgą, balną, pakinktus ir kardą. Žirgą galèjo naudoti ir ūkio darbams dirbti ${ }^{185}$. Pasibaigus 7 mèn. intensyviems mokymams pulke (pulkuose tarnaudavo ne 7, o 18 mèn.), dragūnai, lydimi karininko, vykdavo ị savo apskričių komendantūras. Jei iki komendantūros būdavo ne daugiau kaip 2 dienos žygio, dragūnai vykdavo raiti, jei daugiau - traukiniu. Apskričių komendantūrose jie užsiregistruodavo ir galèdavo grị̌ti namo. Ne tarnybos metu dragūnai uniformą dèvèti ir ginklą nešiotis galejjo šventadieniais, per ịvairias šventes, savo vestuvių proga, vykdami pas vadą ir jam leidus. Kasmet dragūnai 1 mèn. (rugsẻjị-spalị) dalyvaudavo mokymuose. Po $7 \mathrm{~m}$. dragūnas turẻdavo grąžinti ginklus, o jei sveikata leisdavo ir norėdavo turèti tarnybą, galèjo pratęsti ją dar $3 \mathrm{~m}$. Susirgęs žirgas buvo gydomas už kariuomenès lèšas, bet jei tai nutikdavo dèl nepriežiūros, atsakyti turejjo dragūnas. Jis buvo ịpareigotas savo žirgą tinkamai šerti ir prajodinèti, nenualinti jo fiziniu darbu. Tarnybai tinkamais buvo laikomi vyrai, kurie per metus sumokèdavo ne mažiau kaip 100 Lt žemės mokesčio arba kurių tèvai ar globejjai raštu ịsipareigodavo išlaikyti žirgą ir kasmet sumokèti ne mažiau kaip 150 Lt žemès mokesčio ${ }^{186}$. Už 1 ha žemès, priklausomai nuo jos kokybès, buvo mokama nuo 9 iki 1,5 Lt žemès mokesčio kasmet, taigi norintis tapti dragūnu asmuo turẻjo turèti apie 22 ha, o jo tèvas arba globejas - apie 33 ha žemès. Tai maždaug atitiko Lietuvos vidutinio ūkininko valdomos žemès ploto dydį. Ši ùkininkų kategorija buvo gausiausia ir viena svarbiausių valdžios atramų visuomenej $\mathrm{e}^{187} .1935 \mathrm{~m}$. patvirtintose Dragūnų tarnybos įstatymui vykdyti

${ }^{184}$ Dragūnų tarnybos įstatymas. Vyriausybès žinios, Kaunas, 1934, Nr. 442, p. 1-2.

${ }^{185}$ Statkus, V. Lietuvos ginkluotos pajegos 1918-1940 m. Chicago, 1986, p. 152-153.

${ }^{186}$ Michelevičius, B. Mūsų dragūnai. Karys, 1935, Nr. 35, p. 803-804.

187 Žemès ūkio surašymo duomenimis, Lietuvoje buvo 4318514 ha žemès, kuri priklausè 
taisyklèse ${ }^{188}$ buvo smulkiai reglamentuota tarnyba.

Teritoriniams dragūnams buvo perkami 3-5 m. vietinių veislių žirgai, tinkami darbui ir jojimui, vidutinio aukščio, atsižvelgiant ị raitelių, kuriems bus perduotas žirgas, ūgi ${ }^{189}$. Kai kurie dragūnai tarnauti stodavo su savo žirgais ir tik pulkuose atlikdavo karinị rengimą. Tokiais atvejais kariuomenè sumokèdavo už žirgą ${ }^{190}$, t. y. iš dragūno ji nupirkdavo ${ }^{191}$. Bendrąja tvarka dragūnai išsirinkdavo sau žirgus iš pasiūlytų ${ }^{192} .1939 \mathrm{~m}$. buvo

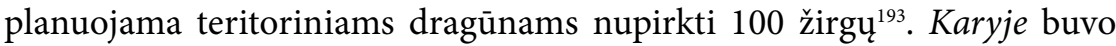
smulkiai išdèstytos dragūnams duotų žirgų priežiūros taisyklès: kaip ir kuo juos šerti, valyti, kokiose patalpose laikyti, taip pat kaip prižiūrèti išduotus ginklus, uniformą ir kitą karinį turtą ${ }^{194}$. Gerai žirgus ir patikètą karinị turtą prižiūrintiems dragūnams buvo mokamos premijos iki $50 \mathrm{Lt}^{195}$. Po $7 \mathrm{~m}$. lygtinių atostogų žirgas ir visas turtas tapdavo kario nuosavybe. Dragūnas, neištarnavęs nustatyto laiko, turèjo grąžinti žirgą, ginklus, balną, šarvus ir atlikti karo prievolę bendrąja tvarka ${ }^{196}$.

1934 m. kiekvieną dragūnų būrį turèjo sudaryti 50 karių: 1 karininkas, 1 būrininkas, 2 skyrininkai, 28 grandies kardų kariai, 16 lengvųjų kulkosvaidžių grandies karių, ūkvedys-pašarininkas ir žirgų kaustytojas. Būrys turèjo būti ginkluotas 47 karabinais, 2 lengvaisiais kulkosvaidžiais, 1 pistoletu, 50 kardų (skirti pikių nenumatyta), turèti 50 šalmų, 730 šovinių,

ūkiams, žemès mokesčio buvo surenkama apie 19,1 mln. Lt. Už 1 ha buvo mokama apie 4,42 Lt mokesčio: Lietuviu enciklopedija, t. XV. Vilnius, 1991, p. 182, 224.

${ }^{188}$ Dragūnų tarnybos ịstatymui vykdyti taisyklès. Vyriausybès žinios, Kaunas, 1935, Nr. 498, p. 4-12.

${ }^{189}$ Garbenis. Dragūno arklio, šarvų, uniformos priežiūra ir naudojimas. Karys, 1936, kovo 5, Nr. 10 (887), p. 231.

${ }^{190}$ Michelevičius, B. Dragūnas - arklio mylètojas. Karys, 1936, sausio 23, Nr. 4 (879), p. 80 .

${ }^{191} 1$-ojo KP vado 1937 m. rugsejo 23 d. raportas. LCVA, f. 1326, ap. 1, b. 274, 1. 83.

192 2-ojo KP vado 1937 m. spalio 11 d. raportas. LCVA, f. 1326, ap. 1, b. 274, 1. 88.

${ }^{193}$ Kariuomenès štabo IV skyriaus viršininkui, žinios apie arklių pirkimą $1939 \mathrm{~m}$. LCVA, f. 929 , ap. 9, b. 209, 1. 17.

${ }^{194}$ Vilkutaitis. Dragūne, tavo uždavinys ir pareigos grižǔus namo. Karys, 1934, lapkričio 2, Nr. 44 (815), p. 910-911; Garbenis. Dragūno arklio, šarvų, uniformos priežiūra ir naudojimas. Karys, 1936, kovo 5, Nr. 10 (887), p. 231-232.

${ }^{195}$ Kavalerijos viršininkas, 1937 m. rugpjūčio 3 d. LCVA, f. 1326, ap. 1, b. 274, 1. 68.

${ }^{196}$ Statkus, V. Lietuvos ginkluotos pajegos 1918-1940 m. Chicago, 1986, p. 865-866. 
4 žiūronus, 4 kompasus, 75 kavalerijos šovinynus, 2 optinius taikiklius, 1 raketsvaidị, 2 balnus kroviniui (su šovinynais ir apkabomis), 8 lengvojo kulkosvaidžio šovinynus su apkabomis. Prieš kautynes kiekvienas kardų grandies karys būtų gavęs 150 šovinių, visi kiti - po 75, lengviesiems kulkosvaidžiams - po 900 šovinių. Visi kariai turejjo būti aprūpinti dujokaukèmis ${ }^{197}$. Būriui buvo numatyta išduoti 36 pèstininkų kastuvus, 2 sulankstomus pjūklus, 4 žirkles vielai kirpti, 4 mažus pėstininkų kirvius ir t. t. ${ }^{198}$ Pagal parengtus teritorinių dragūnų kardų būrio etatus padalinyje turèjo būti 41 karys ( 1 karininkas, 1 vyresnysis puskarininkis, 3 jaunesnieji puskarininkiai, 6 grandiniai, 30 eilinių) ir 41 žirgas. Pėsti kautynių metu turèjo veikti 28 kariai, likusieji būtų likę saugoti žirgų ${ }^{199}$. Vèlesniais metais dragūnų būrių karių skaičius buvo sumažintas, tačiau suplanuoti dviejų tipų būriai - raitųjų žvalgų ir divizijų lengvųjų rinktinių.

$1934 \mathrm{~m}$. planuota suformuoti 2, $1935 \mathrm{~m}$. - 4, o 1936-1940 m. kasmet po 6 teritorinių dragūnų būrius ${ }^{200}$, taigi iš viso per $7 \mathrm{~m}$. - 36 teritorinių dragūnų būrius. Apskritai per 7 m. (1935-1941 m.) numatyta visoje Lietuvoje, išskyrus Klaipedos kraštą, suformuoti 36 dragūnų būrius po 34 arba 51 karị, iš viso juose būtų buvę 1292 vyrai. Tikètasi turèti dragūnų 4 raitụjų žvalgų būriams po 51 karị ir 1088 dragūnus 4 DLR (iš 8 būriụ po 34 karius $)^{201}$. Tačiau faktiškai planų igyvendinti nepavyko, nes $1934 \mathrm{~m}$. ì teritorinius dragūnus buvo priimti 72 vyrai, 1935 m. - 13, o 1936 m. 42 , per $3 \mathrm{~m}$. iš viso - 127 dragūnai ${ }^{202}$, taigi beveik 4 būriai, nors planuota suformuoti 12. Sudariusi planą karinè vadovybė $1935 \mathrm{~m}$. tikejosi surinkti apie 200 dragūnų, o surinkta tik 100, 1936 m. planuota priimti 220-225 dragūnus, tačiau buvo priimti tik 98.1936 m. pabaigoje tikètasi turèti 370 dragūnų, o buvo viso labo 133, t. y. 36 \% numatyto skaičiaus. Dvejų metų (1935-1936 m.) patirtis parode், kad „nei naujokai, nei kavalerijos atsargos

${ }^{197}$ Dragūnų būrio ginklavimo turto lentelè, 1934 m. gruodžio 1 d. LCVA, f. 1326, ap. 1, b. $184,1.51$.

${ }^{198}$ Dragūnų būrio techniško turto lentelè, 1934 m. gruodžio 1 d. LCVA, f. 1326, ap. 1, b. $184,1.53$.

${ }^{199}$ Dragūnų kardų būrio sudètis. Priedas Nr. 1 prie Laikino dragūnų statuto. LCVA, f. 561 , ap. 18 , b. $101,1.215$.

200 Tiekimų viršininkui, 1934 m. gegužès 25 d. LCVA, f. 1, ap. 1, b. 398, 1. 24.

${ }^{201}$ Pranešimas dragūnų formavimo reikalu, 1937 m. LCVA, f. 929, ap. 5, b. 509, 1. 12.

${ }^{202}$ Kavalerijos štabo 1937 m. vasario 19 d. raportas. LCVA, f. 929, ap. 5, b. 509, 1. 8. 
kareiviai dragūnais tarnauti nenori“. Karinè vadovybẻ konstatavo: 1) apskričių komendantai negalëjo surinkti ị dragūnų tarnybą numatyto naujokų skaičiaus; 2) per 7 mèn. tarnybos kariuomeneje labai daug dragūnų „nubyredavo“, $1936 \mathrm{~m}$. atsisake tarnauti apie $61 \%$; 3) kavalerijos atsargos kariai į dragūnų tarnybą nestojo. Buvo įvardytos penkios priežastys: 1) vyrų nenoras $7 \mathrm{~m}$. įsipareigoti kariuomenei ir kasmet 1 mèn. dalyvauti kariniuose mokymuose; 2) baimé prisiimti atsakomybę už valdišką turtą, žirgą, jo reikmenis ir ginklus; 3) per menka materialinè motyvacija; 4) patriotizmo ir karingumo stoka; 5) propagandos trūkumas ${ }^{203}$. Žinoma, svarbu pažymèti, kad teritoriniais dragūnais vyrai galëjo tapti tik tose apskrityse, kuriose kariné vadovybé buvo numačiusi formuoti tokius padalinius ${ }^{204}$. Be to, teritoriniais dragūnais galejo tarnauti tik kavalerijos daliniuose atlikę karo tarnybą, norintys tapti dragūnais kitų kariuomenès rūšių kariai turejjo bendra tvarka prašyti, kad juos perkeltų i kavalerijos dalinį ${ }^{205} .1936 \mathrm{~m}$. rugséjo mén. buvo pašaukti vienam ménesiui visi lygtinių atostogų išleisti ir atsargos teritoriniai dragūnai ${ }^{206} .1936 \mathrm{~m}$. rugsèjo $8 \mathrm{~d}$. Gaižiūnų poligone vyko Tautos šventė. Jos metu parade kartu su visais kavalerijos pulkais dalyvavo ir teritorinių dragūnų eskadronas ${ }^{207}$.

1937 m. pavasarị iš 11 Ukmergès apskrityje pašauktų atlikti karo prievolès ir pareiškusių norą tapti teritoriniais dragūnais tinkamais buvo pripažinti tik 2 asmenys, nes dauguma neturèjo pakankamai žemès ir nemokejo nustatyto minimalaus žemés mokesčio ${ }^{208} .1937 \mathrm{~m}$. Mažeikių apskrities komendantas Kavalerijos štabui pranešè, kad tais metais norinčių stoti $\mathfrak{i}$ teritorinių dragūnų tarnybą neatsirado ${ }^{209}$, tą patị pranešè Tauragè ${ }^{210}$, Tel-

\footnotetext{
${ }^{203}$ Pranešimas dragūnų formavimo reikalu, 1937 m. LCVA, f. 929, ap. 5, b. 509, 1. 12-14. ${ }^{204}$ Patarimai. Trimitas, 1935, rugpjūčio 29, Nr. 35 (768), p. 641.

${ }^{205}$ Kavalerijos štabo viršininko 1937 m. vasario 5 d. raštas 1-ojo PP vadui. LCVA, f. 1326, ap. 1, b. 274, 1. 22.

206 Iš karių gyvenimo. Trimitas, 1936, rugsèjo 3, Nr. 36 (821), p. 865.

${ }^{207}$ Iš karių gyvenimo. Trimitas, 1936, rugsèjo 10, Nr. 37 (822), p. 890.

${ }^{208}$ Ukmergès apskrities 1937 m. pavasario įkadravimo norinčių būti dragūnais žinios, 1937 m. sausio 12 d. LCVA, f. 1326, ap. 1, b. 274, 1. 6-9.

${ }^{209}$ Mažeikių apskrities komendanto 1937 m. sausio 13 d. raportas. LCVA, f. 1326, ap. 1, b. $274,1.10$.

${ }^{210}$ Tauragès apskrities komendanto $1937 \mathrm{~m}$. sausio 15 d. raportas. LCVA, f. 1326, ap. 1, b. $274,1.11$.
} 
šių ${ }^{211}, K^{2}$ Kauno ${ }^{212}$ apskrities komendantai, Kretingos apskrityje tokių buvo $14^{213}$, Šiaulių apskrityje - $11^{214}$, Marijampolès $-4^{215}$, Šakių - $4^{216}$, Rokiškio $5^{217}$. Kavalerijos štabas $1937 \mathrm{~m}$. apskričių komendantus informavo, kad teritorinių dragūnų tarnybai iš pasiūlytųjų Kretingos apskrityje tiko 10, Šiaulių - 7, Utenos - 3, Alytaus - 1, Vilkaviškio - 2, Šakių - 4, Ukmergès 1, Rokiškio - 5, Raseinių - 1, Panevėžio - 13, Marijampolès - 4, Biržų - 5 vyrai $^{218} .1937$ m. rugsejji i 3 3-iąji KP iš Tauragès, Šiaulių ir Raseinių apskričių ị karinius pratimus atvyko 50 dragūnų su 49 žirgais, o turẻjo atvykti 52 dragūnai219. I 1-ąji KP iš Panevėžio ir Ukmergès apskričių atvyko 46 dragūnai su žirgais, nors turèjo atvykti $55^{220}$, o ị 2-ąji KP atvyko 18 dragūnų su 16 žirgų, kai planuota sulaukti 19 dragūnų su žirgais ${ }^{221}$. Dalis dragūnų atvyko be žirgų, nes tuo metu gyvuliai sirgo ${ }^{222}$. 1-ojo KP štabas raportavo: „Žmonès fiziškai tvirti ir morale gera. Paliuosuoti du. Arkliai gerame kūne. Paliuosuotas vienas. Šarvuotè gera. “223

1937 m. rudeni, pasibaigus mokymams, naujiesiems teritoriniams dragūnams buvo pasiūlyti seni vokiški balnai, bet šie atsisakẻ juos imti, esą

\footnotetext{
211 Telšių apskrities komendanto 1937 m. sausio 19 d. raportas. LCVA, f. 1326, ap. 1, b. $274,1.19$.

${ }^{212}$ Kauno miesto ir apskrities komendanto $1937 \mathrm{~m}$. sausio 21 d. raportas. LCVA, f. 1326, ap. 1, b. $274,1.20$.

${ }^{213}$ Kretingos apskrities 1937 m. pavasario įkadravimo norinčių būti dragūnais žinios, 1937 m. sausio 19 d. LCVA, f. 1326, ap. 1, b. 274, 1. 12-13.

214 Šiaulių apskrities $1937 \mathrm{~m}$. pavasario ịkadravimo norinčių būti dragūnais žinios, 1937 m. sausio 19 d. LCVA, f. 1326, ap. 1, b. 274, 1. 14-16.

${ }^{215}$ Marijampolès apskrities $1937 \mathrm{~m}$. pavasario ịkadravimo norinčių būti dragūnais žinios, 1937 m. sausio 19 d. LCVA, f. 1326, ap. 1, b. 274, 1. 18.

216 Šakių apskrities 1937 m. pavasario ịkadravimo norinčių būti dragūnais žinios, 1937 m. vasario 4 d. LCVA, f. 1326, ap. 1, b. 274, 1. 23.

${ }^{217}$ Rokiškio apskrities komendanto 1937 m. vasario 4 d. raportas. LCVA, f. 1326, ap. 1, b. 274, 1. 11 .

${ }^{218}$ Kavalerijos štabas apskričių komendantams 1937 m. vasario 15 d. LCVA, f. 1326, ap. 1, b. 274, 1. 29-40.

219 3-iojo KP vado 1937 m. rugsejjo 1 d. raportas. LCVA, f. 1326, ap. 1, b. 274, 1. 105. ${ }^{220}$ 1-ojo KP vado 1937 m. rugsejo 2 d. raportas. LCVA, f. 1326, ap. 1, b. 274, 1. 106.

${ }^{221}$ 2-ojo KP vado 1937 m. rugsèjo 2 d. raportas. LCVA, f. 1326, ap. 1, b. 274, 1. 107. 222 3-iojo KP vado 1937 m. rugsejjo 4 d. raportas. LCVA, f. 1326, ap. 1, b. 274, 1. 108. ${ }^{223}$ 1-ojo KP vado 1937 m. rugsèjo 5 d. raportas. LCVA, f. 1326, ap. 1, b. 274, 1. 112.
} 
balnai turètų būti nauji ir tarnauti ilgai ${ }^{224}$. Kavalerijos viršininkas lygtinių atostogų išleidžiamiems teritoriniams dragūnams įsakè išduoti lietuviškus balnus ir pabalnes, ne senesnius kaip $1936 \mathrm{~m}$. (pradèti naudoti) ${ }^{225} .1938 \mathrm{~m}$. 12 apskričių (Panevėžio, Biržų, Rokiškio, Ukmergès, Utenos, Marijampolès, Alytaus, Vilkaviškio, Šakių, Šiaulių, Raseinių ir Kretingos) komendantai ị teritorinius dragūnus atrinko 40 kandidatų, balandžio $1 \mathrm{~d}$. tiek vyrų turèjo būti pasiųsta mokytis į 2-ąj $\mathrm{KP}^{226}$.

Teritoriniai dragūnai buvo tiesiogiai pavaldūs Kariuomenès štabui, todèl 1938 m. I PD susiruošus atlikti žiemos lauko pratimus, paprašyta, kad kariuomenès vadas pašauktų Panevėžio (36 dragūnus) ir Ukmergès (30 dragūnų) karius dalyvauti 5 d. divizijos mokymuose ${ }^{227}$. Kavalerijos viršininkas 1938 m. į pratybas poligone ir rudens manevrus Kariuomenès štabo prašè pašaukti visus lygtinių atostogų išleistus teritorinius dragūnus ${ }^{228}$. 1938 m. rudenị $\mathfrak{i}$ karinius pratimus, kurie turejo vykti nuo rugpjūčio 19 iki rugsèjo 19 d. Gaižiūnų poligone, buvo planuojama iš 14 apskričių pašaukti 176 teritorinius dragūnus, išleistus lygtinių atostogụ ${ }^{229}$. Daugumos apskričių dragūnai ị poligoną turèjo atvykti geležinkeliu, kelių artimesnių (Panevėžio, Ukmergès, Alytaus ir Seinų) - raiti „žygio tvarka“230. 1939 m. ị karinius pratimus planuota pašaukti 211 teritorinių dragūnų ${ }^{231}$, mokymai

\footnotetext{
224 3-iojo KP vado 1937 m. spalio 19 d. raportas. LCVA, f. 1326, ap. 1, b. 274, 1. 99.

${ }^{225}$ Kavalerijos viršininko 1937 m. spalio 21 d. įsakymas. LCVA, f. 1326, ap. 1, b. 274, 1. 100.

${ }^{226}$ Kavalerijos viršininko 1938 m. kovo 9 d. raportas. LCVA, f. 929, ap. 5, b. 538, 1. 26, 28.

${ }^{227}$ Kariuomenès štabo III skyriaus 1938 m. sausio 28 d. raportas. LCVA, f. 929, ap. 5, b. $538,1.22$.

${ }^{228}$ Kavalerijos viršininko 1938 m. birželio 11 d. raštas. LCVA, f. 929, ap. 5, b. 538, 1. 41.

${ }^{229}$ Iš Tauragès apskrities - 17, Panevėžio - 36, Šiaulių - 39, Marijampolès - 21, Ukmergès - 29, Alytaus - 5, Seinų - 1, Raseinių - 4, Vilkaviškio - 2, Biržų - 5, Šakių - 3, Utenos - 3, Rokiškio - 4, Kretingos - 7 teritoriniai dragūnai, išleisti lygtinių atostogų: Lygtinių atostogų dragūnams karo pratimų šaukti tvarkaraštis, $1938 \mathrm{~m}$. birželio $14 \mathrm{~d}$. LCVA, f. 929, ap. 5, b. 538, 1. 38. Nors Alytaus apskrityje gyveno tik 3 teritoriniai dragūnai: Alytaus apskrities komendanto 1938 m. birželio 22 d. raportas. LCVA, f. 929, ap. 5, b. 538, 1. 46.

${ }^{230}$ Paleistų dragūnų S. A. sąrašas, 1938 m. LCVA, f. 929, ap. 5, b. 538, 1. 42.

${ }^{231}$ Iš Biržų apskrities - 7, Panevèžio - 49, Ukmergès - 31, Rokiškio - 8, Utenos - 4, Alytaus - 7, Marijampolès - 22, Seinų - 2, Šakių - 4, Vilkaviškio - 3, Tauragès - 17, Šiaulių 44, Kretingos - 9, Raseinių - 4 teritoriniai dragūnai: Karinių pratimų atlikti pašauktų teritorinių dragūnų surinkimo, prièmimo ir vykimo ị pulkus tvarkaraštis, 1939 m. LCVA,
} 
turejo vykti rugsèjo 4-28 d. ${ }^{232}$ Tačiau dèl kilusio Lenkijos ir Vokietijos karo Lietuvos kariuomenès didieji rudens manevrai buvo atideti ir teritorinių dragūnų ị mokymus ịsakyta nešaukti ${ }^{233}$.

1936 m. Trimite teigiama: „Tenka manyti, kad dragūnų tarnyba krašte žymiai išsiplès, nes ji naudinga tiek patiems stojantiesiems ị dragūnų tarnybą, tiek kariuomenès ir krašto reikalams. “234 Tačiau tais pačiais 1936 m. Panevėžio apskrities komendantas pranešè, kad „dèl papildymo Panevèžio apskrities dragūnų būrio iki pilnos etatinès sudèties jau ne kartą buvo raginami ir daromi atskiri pasiūlymai dragūnų tarnybos sąlygoms atitinkantiems kavalerijos atsargos kareiviams stoti ị dragūnus, bet ligi šiol [1936 m. - V. J.] šios priemonès žymesnių rezultatų nedavė, ir dragūnų būrio papildymas vyksta gana lètai. Tas aiškinama dalinai tuom, kad jau atlikę karinę prievolę kavalerijos atsargos kareiviai vengia vèl susirišti su karo tarnyba ir bijo prisiimti atsakomybę už duodamą arklị ir kitą valdišką turtą. Be to, pati dragūnų tarnyba per mažai buvo reklamuojama. “235

Panevėžio apskrities komendanto teigimu, $1937 \mathrm{~m}$. apskrityje buvo apie 60 jaunuolių, norinčių ir pagal teisès aktus tinkamų būti teritoriniais dragūnais, tačiau užsirašè tik 9 . Pasak komendanto, taip nutiko dèl to, kad per mažai žinoma apie teritorinio dragūno tarnybos sąlygas ir nèra propagandos. Komendantas su kiekvienu kandidatu turejjo kalbėtis 10-15 min., aiškindamas šios tarnybos įstatymą. Todèl pasiūlè teritorinių dragūnų tarnybai propaguoti išleisti specialią brošiūrą su nuotraukomis apie kavaleriją. Be to, kiekvienais metais iš KP atvykęs karininkas šiais tikslais galètų pravesti vietos dragūnų pratybas. Taip būtų skatinami vidutiniai ir pasiturintys ūkininkai ir jų sūnūs rinktis teritorinių dragūnų tarnybą ${ }^{236}$.

1938 m. komendanto paminèti sunkumai dèl naujokų priemimo ị teritorinių dragūnų tarnybą buvo panašūs ị kilusius prieš dvejus metus -

f. 929 , ap. 3, b. 1122, 1. 11.

${ }^{232}$ Kavalerijos viršininko 1939 m. liepos 29 d. nurodymai dragūnams, esantiems lygtinèse atostogose, kariniams pratimams šaukti. LCVA, f. 929, ap. 3, b. 1122, 1. 10-10 apv. 1.

${ }^{233}$ Kariuomenès štabo III skyriaus 1939 m. rugpjūčio 30 d. ịsakymas. LCVA, f. 929, ap. 3, b. $1122,1.17$.

${ }^{234}$ Iš karių gyvenimo. Trimitas, 1936, rugsèjo 24, Nr. 39 (824), p. 937.

${ }^{235}$ Panevėžio apskrities komendanto 1936 m. sausio 22 d. raportas. LCVA, f. 929, ap. 5, b. $538,1.45$.

${ }^{236}$ 1-ojo KP vado 1937 m. lapkričio 5 d. raportas. LCVA, f. 1326, ap. 1, b. 274, 1. 276. 
1936 m. ${ }^{237}$ Tad I PD vadas, remdamasis Panevėžio apskrities komendanto raportu, 1938 m. kariuomenès vadui pateikè siūlymą: „Laikau būtinu reikalu atkreipti rimtą dèmesị ị dragūnų institucijos propagandą, jeigu norima, kad ta institucija nebepasiliktų merdejanti. Dèl propagandos stokos ne tik nèra pasirinkimo imant naujokus - dragūnus, bet sutinkami dideli sunkumai iš viso pririnkti tų pageidaujamą jų skaičių. Atrodo, kad propagandai reikètų panaudoti gražius spalvotus plakatus, platinti lapelius, raginančius stoti dragūnuosna. Ypatingai reikalinga propaganda tose apskrityse, iš kurių tais metais numatoma imti ị dragūnus. Dragūnų tarnybos istatymą reikètų papildyti ta prasme, kad dragūnai, važiuodami traukiniais uniformoje, naudojasi pravažiavimui tokiomis pat lengvatomis, kaip ir būtinosios tarnybos kareiviai." ${ }^{238}$

Patyrus nesèkmę formuojant teritorinių dragūnų būrius, buvo susirūpinta propaganda: „Imkim sau toks dragūnų ịstatymas. Mums, kariams, labai aiški šio ịstatymo reikšmė. Bet ar ji pakankamai aiški tiems, kurie yra svarbiausi šio įstatymo vykdytojai? Turbūt nesuklysiu pasakęs, kad jei būtų organas arba tam tikras biuras, kuris ši ịstatymą ir jo teikiamą naudą Lietuvos visuomenei išaiškintų plačiau - dragūnų organizavimo darbas galètų žymiai prasiplèsti, o drauge ir žymiai palengvèti. <...> O juk turètų būti organas, kuris pasakytų kiekvienam inteligentui, kad tèvynès labui reikalinga, jog jis baigtų karininkų-aspirantų kursus; tas organas paskatintų didesnio ūkininko sūnų stoti ị dragūnų eiles (jei jo apskrityje dragūnai organizuojami) ne dèl asmeniškų išskaičiavimų, bet todèl, kad tuo tèvynei naudingesnis bus. " 239

1937 m. šauktinis iš Šakių apskrities Vitas Urbonavičius atsisakẻ stoti $\mathfrak{i}$ teritorinių dragūnų tarnybą motyvuodamas tuo, kad šeimoje yra vienintelis darbingas vyras, o mokymai vyks ne žiemą, t. y. laisvu nuo ūkio darbų laiku, bet rudeni, kai darbymetis. Karys buvo paliktas 2-ajame KP atlikti privalomosios karo tarnybos ${ }^{240}$. Spaudoje buvo rašoma, kad „mūsų Krekenavos apylinkejj vienas dragūnas tik metai, o jau arklị visai užvaikè. Toks

\footnotetext{
${ }^{237}$ Panevėžio apskrities komendanto 1938 m. kovo 15 d. raportas. LCVA, f. 929, ap. 5, b. $538,1.44$.

${ }^{238}$ I PD vado 1938 m. kovo 22 d. raportas. LCVA, f. 929, ap. 5, b. 538, 1. 43.

${ }^{239}$ Aras, V. Kariškokios propagandos reikalu. Kardas, 1935, gegužès 1, Nr. 9 (214), p. 190.

240 2-ojo KP vado 1937 m. rugsèjo 30 d. raportas. LCVA, f. 1326, ap. 1, b. 274, 1. 84.
} 
arklys greit visai netiks kariniams reikalams" ${ }^{241}$.

Teritorinių dragūnų tarnybos nepopuliarumą rodo ir klausimas, pateiktas Trimite: „Esu karys dragūnas, vedęs. Ar dèl šeimyninių - ūkiškų sunkumų galiu būti atleistas nuo kartotinių karo pratimų?" Buvo išspausdintas ir atsakymas: „Turbūt tamsta atmeni, kokị pasižadèjimą esi davęs, stodamas ị dragūnus, ir kokias esi igijęs teises bei pasièmęs priedermes. Jei pamiršai, nueik ị komendantūrą, kurioje ị dragūnus stojai. Ten tamstai visa išaiškins. “242

1938 m. pilietis B. K. kreipèsi ị karinę vadovybę prašydamas sūnų, 1935 m. tapusị teritoriniu dragūnu, perkelti ị kitą vietą, nes, pasak jo, sūnus girtauja, verda naminę, smurtauja ir grasina ji nužudyti. Šio teritorinio dragūno tèvas patvirtino savo įsipareigojimą ir toliau išlaikyti žirgą $a^{243}$. Nors iki 1939 m. buvo numatyta suformuoti 24 būrius po 36 dragūnus (iš viso surinkti 864 raitelius), $1939 \mathrm{~m}$. vasarą Lietuvoje buvo tik 211 teritorinių dragūnų $u^{244}$, t. y. kiek daugiau nei 6 būriai. Be to, reikia ịvertinti tai, kad nuo $1939 \mathrm{~m}$. Lietuvos kariuomenè karo atveju planavo mobilizuoti jau ne 4, o 5 pèstininkų divizijas, taigi ir teritorinių dragūnų reikejjo ne 4, o 5 DLR ir raitųjų žvalgų būriams, t. y. dar 323 .

Spaudoje optimistiškai buvo rašoma, kad dragūnų tarnyba prisidès prie jojimo sporto, kuriam pradžią dave šauliai dragūnai ir Vytijos raitininkai, Lietuvos kaime pletojimo ${ }^{245}$. Pastaroji organizacija buvo ịkurta prie Kūno kultūros rūmų, jos pagrindą sudarè kavalerijos karininkai. Vytija buvo ịkurta jojimo sportui krašte populiarinti ${ }^{246}$. Tarpukariu buvo aktyviai rūpinamasi žirgų sporto ir apskritai žirgininkystès plètra, 1924 m. įsteigta Lietuvos raitininkų sąjunga, 1933 m. - Vytija - organizacijos, kurios turès atgaivinti „raitelio dvasią“, puoselèti tautines tradicijas ${ }^{247}$. Dragūnams kai-

\footnotetext{
${ }^{241}$ Patarimai. Trimitas, 1936, balandžio 9, Nr. 15-16 (800-801), p. 382.

242 Patarimai. Trimitas, 1936, rugpjūčio 13, Nr. 33 (818), p. 801.

${ }^{243}$ Krašto apsaugos ministrui, 1938 m. vasario 5 d. LCVA, f. 929, ap. 5, b. 538, 1. 35.

${ }^{244}$ Karinių pratimų atlikti pašauktų teritorinių dragūnų surinkimo tvarkaraštis, $1939 \mathrm{~m}$. liepos 29 d. LCVA, f. 929, ap. 3, b. 1122, 1. 11.

${ }^{245}$ Atsarg. Eiva. Dragūnai kaime. Karys, 1935, sausio 24, Nr. 4 (827), p. 89.

${ }^{246}$ Plačiau apie Vytijos ịkūrimą ir tikslus žr.: K-tis, J. Kas toji Vytija? Karys, 1934, kovo 29, Nr. 13 (784), p. 252-253.

${ }^{247}$ Tamošiūnas, M. Lietuvos kariuomenés kavalerija 1919-1940 m.: tradicijos, kasdienybe, vizijos. [Baigiamasis bakalauro darbas, Kaunas, 2013], žr.: http://www.antraspasaulinis.
} 
me kelti ir tam tikri kultūriniai uždaviniai: skaityti, dalintis su kitais karine periodika, bendradarbiauti su vietos šauliais dragūnais ir Vytijos raiteliais, prisidèti prie visuomenès karinio rengimo, prie žirgų sporto plètojimo ir jų priežiūros kultūros kẻlimo. Žinoma, siekta, kad dragūnai aktyviai dalyvautų bendruomenių kultūrinejje, kooperatyvų veikloje ir t. t. ${ }^{248}$

Dragūnų uniforma buvo išeiginis rūbas, savo spalvingumu traukiantis dèmesį $i^{249}$. Karininkams, ištarnavusiems ne mažiau kaip $3 \mathrm{~m}$., atlikusiems visus pratimus ir gerai atestuotiems, galèjo būti suteiktas aukštesnis laipsnis, bet ne aukštesnis kaip kapitono, dragūnams po $2 \mathrm{~m}$. tarnybos - ne aukštesnis kaip viršilos ${ }^{250}$.

Analogiška teritorinè kavalerijos tarnyba egzistavo ir Čekoslovakijoje $\mathrm{e}^{251}$. Lenkijoje taip pat veikè teritorinè kavalerijos struktūra - Krakusi (lenk. Przysposobienia Wojskowego Konnego), jos raiteliai 1939 m. dalyvavo mobilizuojant pėstininkų divizijų raitųjų žvalgų būrius ${ }^{252}$. Panaši kavalerijos rezervo kūrimo sistema veikè ir Rumunijoje, kurios tarpukario spaudoje kavaleristai buvo skirstomi $\mathfrak{i}$ „rošiori“ ir „kalaraši“ (Rosiori ir Cãlãrasi) tarnybas, t. y. i̇ reguliariąją ir teritorinę. I teritorinę kariuomenę buvo imami $21 \mathrm{~m}$. savanoriai, pasižadeję: 1) turèti nuosavą 5-7 m. žirgą, tinkamą kavalerijai; 2) visam tarnybos laikui savo lešomis ịsigyti reikiamą dangą; 3) ìšeję i atsargą $4 \mathrm{~m}$. išlaikyti tarnybai tinkamą žirgą ir uniformą. Toks pašauktas karys prilygo būtinosios karo tarnybos kavaleristui, jis pulke gaudavo skirtus ginklus, maisto sau ir pašaro žirgui. Cãlãrasi tarnybos karys ị kariuomenę stodavo balandžio $1 \mathrm{~d}$. ir po 3-4 mèn. pradinio karinio

net/e107_plugins/content/content.php?content.1243

${ }^{248}$ Steponavičius, A. Kultūriniai dragūnų uždaviniai kaime. Karys, 1935, balandžio 4, Nr. 14 (837), p. 333.

249 Vilkutaitis. Dragūne, tavo uždavinys ir pareigos grị̌us namo. Karys, 1934, lapkričio 2, Nr. 44 (815), p. 910-911.

${ }^{250}$ Statkus, V. Lietuvos ginkluotos pajegos 1918-1940 m. Chicago, 1986, p. 865-866.

${ }^{251}$ Vadintus „Selska jizda“: Čekoslovakija. Naujas krašto apsaugos ministeris. Kardas, 1935, liepos 1, Nr. 13 (218), p. 291.

${ }^{252}$ Wojciechowski, J. S. Przysposobienie Wojskowe Konne „Krakusi“ - kawaleria dywizyjna. Przeglad Historyczno-Wojskowy, 2006, Nr 1 (211), s. 5-34; Roguski, R. Rola Przysposobienia Wojskowego Konnego Krakusów w systemie obronnym południowego Podlasia i wschodniego Mazowsza w okresie II Rzeczypospolitej. Rocznik Minsko-Mazowiecki, 2010, t. XVIII, s. 45-53. 
rengimo 40-50 d. buvo paleidžiamas namo ūkio darbų nudirbti. Prieš vykdamas atostogų ginklus ir žirgo šarvuotę palikdavo pulke, o žirgą ir dangą pasiimdavo kartu. Rugsẻjo mėn. kariai vèl grịždavo ị dalinius dalyvauti rudens manevruose, o po jų gaudavo $1 \mathrm{~m}$. atostogų. I pulką jie turejdavo grịžti tik kitų metų rugsèji-spalį, kad vèl dalyvautų manevruose. Taip antraisiais metais 2 mèn. pratybomis karys baigdavo savo aktyviąją tarnybą. Šių dvejų tarnybos metų laikotarpiu karys, bet kada pašauktas, turejjo atvykti i savo pulką. Po to dar $4 \mathrm{~m}$. jis kaip atsargos karys likdavo pulko sąrašuose ir kasmet 2 kartus turèdavo atvykęs su žirgu užsiregistruoti savo pulke. Pirmieji tokie kariai iš valstybès gaudavo tam tikrų lengvatų: buvo atleidžiami nuo kai kurių valstybinių ir savivaldybių mokesčių, tarnybos pulkuose metu netoli savo igulų gyvenantys švenčių proga gaudavo $24-48$ val. atostogų. Pagal i̊statymą ỉ šią tarnybą galèjo stoti vyrai, gyvenantys ne toliau kaip $80 \mathrm{~km}$ nuo kavalerijos dalinio, kuriame tarnaus, dislokacijos vietos. Iš turtingiausių kaimo gyventojų kilę šie kariai buvo patriotiškai nusiteikę ir patikimi. Karys, netekęs žirgo ne karinių mokymų metu, turẻjo savo lěšomis įsigyti kitą. Miestų gyventojai taip pat galejo atlikti analogišką, tik sutrumpintą (ne 2 m., o 7-8 mèn.) tarnybą kavalerijos daliniuose. Miestiečiai, negalintys išlaikyti žirgo, ji nupirkdavo ir padovanodavo kariuomenei ir visus $6 \mathrm{~m}$. su šiuo žirgu tarnaudavo. Taip Rumunijos kariuomenès kavalerijos pulkai kasmet gaudavo 20-30 dovanotų žirgų. Tokiomis priemonèmis Rumunijos kariuomenè užsitikrino kavalerijos pulkams papildyti reikiamą rezervo karių skaičių, taikos metu pulkuose nelaikydavo daug žirgų ${ }^{253}$.

\section{Išvados}

Tarpukariu Lietuvos, kaip ir kitų Europos valstybių, kariuomenės kavalerija tebebuvo tradicinė judri ginklo rūšis. Kavaleristai buvo rengiami kautis pėsti, žirgai iš esmès naudoti dažniausiai tik kaip transporto priemonè. Kavalerijos dalinių kovinè vertė priklausė nuo jų judrumo, gebejjimo įveikti sunkiai pereinamas teritorijas ir turimų ugnies priemonių. Di-

${ }^{253}$ R-is. Rumunų kavalerija. Mūsų žinynas, 1938, t. XXXIV, Nr. 6, p. 971-972. 
desnis judrumas ir ugnies galia - tarpukario kavalerijos siektina vystymosi trajektorija.

Lietuvos kavalerija buvo formuojama pagal bendrus europinius principus, pulkus sudarè 4-6 raitelių, 1-2 sunkiụjų kulkosvaidžių eskadronai, ryšių, inžinierių ir vadovavimo padaliniai. Lietuvoje, kaip ir kitose šalyse, prie kavalerijos dalinių buvo priskirti šarvuočiai, tankai ir raitosios artilerijos padaliniai. Reorganizuojant Lietuvos kavalerijos dalinius buvo atsižvelgiama ̣̇ kitų Europos valstybių, ypač kaimyninių, patirtį.

Vèliausiai nuo $1928 \mathrm{~m}$. Lietuvoje pradèta planuoti kurti teritorinès kavalerijos struktūrą, ketinta sukurti Mirties Husarų tarnybą. Tačiau faktiškai sèkmingai veikė raitụjų šaulių, arba šaulių dragūnų, struktūra, ją 1934 m. papilde teritoriniai dragūnai. Taip tikètasi sustiprinti Lietuvos kariuomenès kavalerijos pajègas, kurios karo atveju turejjo greitai mobilizuotis, patikimai dengti pagrindinių pajègų mobilizaciją ir susitelkimą. Toks Lietuvos karinès vadovybès sprendimas buvo inspiruotas Lenkijos kariuomenès gausios kavalerijos grèsmès karo atveju.

Per 7 m. (1934-1940 m.) Lietuvos kariuomenè tikejjosi surinkti pakankamai teritorinių dragūnų divizijų raitųjų žvalgų ir lengvụjų rinktinių būriams suformuoti, t. y. apie 1,3 tūkst., o gal ir daugiau. Tačiau šis planas visiškai žlugo, nes teritorinių dragūnų tarnyba visuomenèje nebuvo populiari. Pridejjus dar kitą teritorinès kavalerijos rūšį - šaulius dragūnus, 1939 m. buvo 1628 teritorinès kavalerijos raiteliai (dragūnai ir šauliai dragūnai), t. y. daugiau nei planavo karinè vadovybé. Nors kartu tenka konstatuoti, kad turimi archyviniai duomenys kol kas neleidžia tiksliai pasakyti, kiek iš mobilizuojamojo amžiaus vyrų buvo šauliai raiteliai ir kiek jų mobilizacijos atveju būtų pašaukta ị kavalerijos dalinius.

Iteikta $2014 \mathrm{~m}$. rugsejo $10 \mathrm{~d}$. 


\section{Santrumpų sąrašas}

DLR - divizijos lengvoji (kavalerijos) rinktinè

$\mathrm{KB}$ - kavalerijos brigada

$\mathrm{KD}$ - kavalerijos divizija

$\mathrm{KP}$ - kavalerijos pulkas

LŠS - Lietuvos šaulių sąjunga

PD - pèstininkų divizija

$P P$ - pèstininkų pulkas

RA - Darbininkų ir valstiečių raudonoji armija (rus. РабочeКрестьянская Красная Армия)

SS - vok. Schutzstaffel (apsaugos rinktinè)

SSRS - Sovietų Socialistinių Respublikų Sąjunga (rus. Союз Советских Социалистических Республик)

ŠAP - automatinis prieštankinis pabūklas 


\title{
LA CAVALERIE DE L'ARMEE LITUANIENNE DURANT L'ENTRE-DEUX-GUERRES : LES REGIMENTS REGULIERS, LES TIREURS-DRAGONS ET LE POSTE DES DRAGONS TERRITORIAUX
}

\author{
Dr. Vytautas JOKUBAUSKAS \\ Institut d'Histoire et d'Archéologie de la Région \\ de la Mer Baltique de l'Université de Klaipéda
}

Durant l'entre-deux-guerres, l'armée lituanienne préparait ses manœuvres militaires en contemplant ses longues frontières ouvertes. En outre, l'un de ses principaux adversaires militaires était la Pologne, qui possédait de nombreuses forces de cavalerie mobiles. D’une part, compte tenu des conditions de son entourage, il était nécessaire à l'armée lituanienne d'avoir des unités mobiles puisque sa motorisation massive était impossible à cause du faible niveau de motorisation dans le pays, du réseau routier peu développé et des ressources matérielles limitées. D’autre part, durant l'entre-deux-guerres, les autres pays européens n'avaient pas complètement abandonné la cavalerie et certains d'entre eux disposaient même de très nombreuses forces de cavalerie, ce qui a poussé l'armée lituanienne à s'efforcer d'obtenir le plus de forces possible.

Durant l'entre-deux-guerres, après les luttes pour l'indépendance qui ont fait rage jusqu'en 1924, l'armée comprenait 3 régiments de cavalerie, dont l'un fut dissous et seulement deux furent maintenus, les régiments de Hussards et de Uhlans, pendant la période de paix, entre 1924 et 1935. Puis le régiment de dragons fut réinstauré en 1935. Cependant, en complément des unités régulières de cavalerie, des préoccupations concernant la nécessité de créer une structure de cavalerie territoriale furent soulevées à la fin des années 1920, et ce dans l'espoir d'augmenter le nombre de personnes formées militairement ainsi que le nombre de chevaux afin de pouvoir mobiliser, en cas de guerre, de nouvelles unités de cavalerie dans les meilleurs délais. 
En 1934 il fut prévu que la mise en place, en sept ans (1935-1941), du poste des dragons territoriaux accueillerait environ 1300 dragons; Néanmoins, en 1939, il n'y en avait que 211, bien qu'en les additionnant au nombre de tireurs-dragons il y avait en tout 1628 cavaliers territoriaux en Lituanie à la date mentionnée, c'est-à-dire plus que ce que le commandement militaire avait prévu de mobiliser pour les troupes sélectionnées de cavalerie d'éclaireurs et les divisions légères. 


\title{
LITHUANIAN ARMY CAVALRY DURING THE INTERWAR PERIOD: REGULAR REGIMENTS, SHOOTERS - DRAGOONS, AND TERRITORIAL DRAGOON SERVICE
}

\author{
Dr Vytautas JOKUBAUSKAS \\ Institute of Baltic Region History and \\ Archaeology of Klaipeda University
}

During the interwar period, and bearing in mind its long and open borders, the Lithuanian army was preparing for a war of manoeuvres. In addition, Poland was considered to be one of the main military enemies, which had numerous mobile cavalry forces. Given these circumstances, on the one hand it was necessary to have mobile units. Mass motorisation of the Lithuanian army due to the country's low level of motorisation, poorly developed road network and limited material resources was impossible. On the other hand, during the interwar period, other European countries had not yet completely abandoned the cavalry, and some had very numerous cavalry forces. This in turn led to attempts to increase the cavalry forces in the Lithuanian army too.

During the interwar period, and after the independence struggles, which continued until 1924, there were three cavalry regiments in the army. Following the disbandment of one regiment between 1924 and 1935 only two cavalry forces remained - the Hussars and the Uhlans regiments in peacetime. In 1935, the Dragoon regiment was again restored. However, at the end of the 1930s, in addition to regular cavalry units it was decided to create a territorial cavalry structure with the hope of increasing the number of militarily trained people and horses on the basis of which it would be possible to mobilise new cavalry units very quickly in case of war.

In 1934, after the establishment of the Territorial Dragoon Service, it was planned to increase the number of dragoons to about 1,300 over seven years (1935-1941). However, by 1939, there were only 211 dragoons, 
although the total number of territorial riders and shooters - the number of dragoons in Lithuania that year was 1,628 , i.e. more than the military leadership planned to conscript into selected squads of equestrian spies and light divisions. 